\title{
Nursing Interventions for Hepatitis C Elderly Patients to Reduce the Side Effects of Pegylated Interferon and Ribavirin and Improve their Quality of
}

\section{Life}

\author{
Raefa Refaat Alam, Lecturer \\ Gerontological Nursing, Faculty of Nursing, Mansoura University \\ Doaa El-Sayed Fadila, Lecturer \\ Gerontological Nursing, Faculty of Nursing, Mansoura University \\ Gamal El-Sayed Shiha, Professor \\ Internal Medicine; GIT and liver unit, Faculty of Medicine, Mansoura University
}

\begin{abstract}
Side effects from hepatitis $C$ treatment can be uncomfortable, sometimes debilitating and rarely even life-threatening for elderly people. With the right planning and support, many of these side effects can be managed which will help in complying with the treatment and in turn improve the quality of life. Objective: To identify the effect of nursing intervention for hepatitis $C$ elderly patients to reduce the side effects of pegylated interferon and ribavirin and improve their quality of life. Setting: The study was carried out at the outpatient clinics of the Specialized Medical Hospital, the General Mansoura Hospital, and the Egyptian Liver Hospital in Dakahlia. Subjects: The study comprised 66 elderly patients with HCV divided into two equal groups of 33 each. Tools: Data was collected using six tools: an interview schedule sheet to assess the socio-demographic and health profile of elders, the short form-36 health survey questionnaire, a checklist to identify medication side effects, fatigue severity scale, geriatric depression scale and nursing intervention program. Results: The main side effects from treatment as reported by the elderly were fatigue, insomnia, bone ache, heart burn, fever, itching and stomatitis respectively. Elderly patients in the study group showed significant improvement in their ratings of perceived fatigue at both 8 and 12 weeks post intervention, while fatigue level for those in the control group did not show any significant change in both evaluations. As well significance improvement in the quality of life post 12 week of intervention in study group was observed. Conclusion: It can be concluded that the side effects and quality of life mean scores improved significantly in the study group compared to control group after 8 and 12 weeks of nursing intervention. Recommendations: Caregivers of elders undergoing hepatitis $C$ treatment should support, motivate and encourage elders to cope with side effects of the hepatitis $C$ therapy.
\end{abstract}

Keywords: Side Effects, Quality of life, Pegylated Interferon and Ribavirin, Elderly.

\section{Introduction}

The high incidence of hepatitis $\mathrm{C}$ virus (HCV) makes it one of the greatest health threats facing the world today. Hepatitis $\mathrm{C}$ is a treatable disease, and over the last few years increasing numbers of patients have been offered antiviral treatment to eradicate the virus. The treatment for $\mathrm{HCV}$ involves a combination of two drugs: pegylated interferon (subcutaneous interferon injection that is given once weekly) and ribavirin tablets that are taken orally daily ${ }^{(1-3)}$. In some patients depending on genotype, this treatment has been shown to induce a sustained viral response (SVR), defined as undetectable hepatitis for six months after the end of 
treatment ${ }^{(4)}$. Studies also reported that patients who don't experience SVR may benefit from the temporary decrease in liver inflammation and fibrosis while taking the treatment. Thus, adherence of patients to therapy is important because it can slow down the disease process. However, treatment is cytotoxic and it is associated with a multitude of adverse side effects ${ }^{(5)}$. Adverse events of antiviral therapy are more prevalent in elderly patients (age $\geq 60$ years) with chronic hepatitis $\mathrm{C}$ than in their younger counterparts, and often interrupt or halt their treatment.

Prevalence of HCV may be different in various regions and various groups of the same community ${ }^{(6)}$. In the Middle East and Africa, the prevalence is highest in Egypt $(18 \%)$ due to past practice of parenteral therapy for schistosomia in the second half of the last century which is responsible for the high prevalence of morbidity and continued endemic transmission of $\mathrm{HCV}$ today $^{(7)}$. Six major HCV genotypes and numerous subtypes have been identified based on molecular relatedness. Genotype 1,2 and 3 have a worldwide distribution, while genotypes 4,5 and 6 are localized to specific geographic locations. In Egypt Genotype 4 is the most prevalent genotype in $\operatorname{Egypt}^{(8)}$.

In USA it is estimated that, more than 100,000 positive hepatitis $\mathrm{C}$ virus patients are over the age of 70 (World Health Organization, 2012). As many as 170 million persons are chronically infected with HCV worldwide and more than 350,000 die annually from liver disease caused by HCV (World Health Organization, 2012) ${ }^{(9)}$. About $10 \%$ to $20 \%$ of those who are chronically infected with hepatitis $\mathrm{C}$ will progress to cirrhosis and 5\% will develop hepatocellular carcinoma. More than $50 \%$ of the patients with hepatcellular carcinoma are elderly over 60 years old ${ }^{(10)}$ HCV infection occurs frequently in elderly individuals approximately $40 \%$ are aged 60 years ${ }^{(11)}$.
The side effects from hepatitis C treatment may be uncomfortable, sometimes debilitating, has a significant negative impact on the health related quality of life (QOL) and rarely, even life-threatening ${ }^{(12,13)}$ and make patient adherence to long term therapy difficult to achieve. Poor adherence to therapy results in inferior sustained virologic response rates. These side effects include fatigue, flue like symptoms, anemia, and anxiety, insomnia, fever, bon ache, and itching $^{(14,15)}$.

Geriatric patients with HCV infection have several age- related changes, such as decreased glomerular filtration rate and decreased liver function that might cause more severe hemolytic anemia with ribavirin and interactions of interferon which were approved for treatment with multi-adverse effects. So the elderly are excluded in several clinical trials, reluctance to treat $\mathrm{HCV}$ therapy related adverse events ${ }^{(10,12)}$.

HCV therapy can affect individuals in many different ways. Fatigue is the primary symptoms, often leading to poor quality of life ${ }^{(16)}$. Other symptoms include nausea, pain, and depression, which can also have a serious impact on the ability to work and on quality of life. Unfortunately $\mathrm{HCV}$ treatment can initially compound and worsen these effects. Side effects such as worsening fatigue, insomnia, alopecia and bone ache are common ${ }^{(17)}$. Side effects can appear in clusters at different times during patient therapy, regardless of their genotype or length of treatment. A study done in Brazil found that, alterations in the quality of life of patients submitted to treatment are mainly related to the somatic side effects of Interferon and Ribavirin and are most noticeable in the first weeks of therapy ${ }^{(18)}$.

Health related quality of life refers to a patient's subjective assessment regarding the physical health, psychological state, social relationships and perception of his/her state of health and which become important aspect of clinical research ${ }^{(19,20)}$. Health related quality of life represents the 
functional effects that an illness and its treatment have upon a patient, as perceived by patient him $\backslash$ herself. The most important domain of elder's QOL is the physical wellbeing which includes the elder's general health conditions and his ability to perform activities of daily living. Psychological well-being includes life satisfaction, achievement and adjustment. Social wellbeing is a multidimensional process that reflects elder's interaction with others ${ }^{(21)}$.

Assessment of health related quality of life has become important aspect of elderly patient's care. With the right planning and support, many side effects can be managed. Support from other people with $\mathrm{HCV}$, friends, and family before and during $\mathrm{HCV}$ treatment plays a key role in coping with side effects ${ }^{(22)}$. Health related quality of life has become a key component in assessment of disease burden, and is particularly valuable for the evaluation of disease management in individuals with chronic disease. In these disease states, mortality risk remains low over a long period of time and many regulatory agencies have accepted HRQL as measure of the effectiveness of intervention of such patients ${ }^{(23,24)}$. Stated that improving compliance with therapy can be enhanced by some measures such as patient education, close follow up, adequate treatment of side effects and minimizing dose changes. While lack of expertise in the proper management of these side effects as well as lack of educating patient may lead to higher rates of drug discontinuation or dose reduction with resultant lower efficacy of treatment. Nurses need to be highly skilled in this area: supervising patient treatment, monitoring side effects; providing patient education counseling and support ${ }^{(25)}$.

Gerontological nurses are in a key position to carry out health education since they are the health care providers who are in continuous contact with patients and their families and have the best opportunities to assess potential problems or side effects, discuss medical regimen and give teaching about all aspects of care which include maintaining physical activity, following dietary modifications and adhering to medication schedule while attending to side effects $^{(23)}$. They also play an important role in supporting hepatitis $\mathrm{C}$ patients and helping them to accept responsibility for their health and well being. The assistance of the nurse in patients counseling about the relative risks, benefits of treatment and management of the side effects is playing an important role in helping the patients to complete a treatment course and therefore adherence to therapy will provide the best chance of achieving a sustained virological response or cure ${ }^{(26,27) \text {. }}$ Thus enhancing their health related quality of life ${ }^{(28)}$.

\section{Aim of the Study}

To identify the effect of nursing intervention for hepatitis $\mathrm{C}$ elderly patients to reduce the side effects of pegylated interferon and ribavirin and improve their quality of life.

\section{Research Hypotheses:}

- The side effects of hepatitis C treatment among hepatitis C elderly patients may be reduced post nursing intervention.

- The quality of life of hepatitis C elderly patients may be improved post nursing intervention.

\section{Research Question:}

What is the effect of nursing intervention for hepatitis $\mathrm{C}$ elderly patients to reduce the side effects of interferon and ribavirin and improve their quality of life?

\section{Materials and Method}

\section{Materials}

Design: Quasi-experimental research design was used in this study.

Setting: This study was conducted at the outpatient clinics of the Specialized Medical 
Hospital, General Mansoura Hospital and Egyptian Liver Hospital in Dakahlia Governorate.

Subjects: The study subjects comprised all HCV elderly patients who attending the previous settings during a period of one year and fulfilling the following criteria:

1. Aged 60 years and more.

2. Receiving pegylated interferon and ribavirin for not more than week.

3. Able to communicate.

4. Accept to participate in the study. Initially $75 \mathrm{HCV}$ elderly patients were enrolled in the study; but only 66 elderly patients completed the study. These were randomly assigned two equal groups: the study group received both the usual hospital care and the planned nursing intervention and the control group received the usual hospital care only.

Tools: In order to collect the necessary data six tools were used:

\section{Tool I: Socio-demographic and Health} Profile Structure Interview Schedule

It was developed by the researchers and included the following data:

1. Socio-demographic characteristics of the study subjects such as age, sex, marital status, level of education, occupation before retirement, living arrangement, income, and source of income.

2. Health Profile of HCV Elderly Patients, it included:

a. Medical history: the duration of $\mathrm{HCV}$ disease, the presence of other co morbidities, and medications used.

b. Laboratory investigations: hemoglobin level, white blood cell count, platelets, Alanine amino transfers, and Asperate amino transfers.
Tool II: Short Form-36 Health Survey Questionnaire (SF-36)

The Short Form-36 Health Survey Questionnaire (SF-36) was developed by Ware and Sherbourne (1992) to be used as a survey of health status ${ }^{(29)}$. It is reported to be a sensitive tool for assessing healthrelated quality of life of hepatitis $\mathrm{C}$ patients (Amodio et al, 2012) ${ }^{(30)}$. The SF-36 is a multi-item scale that measures eight domains of health: physical functioning, role limitations due to physical health, bodily pain, general health perceptions, vitality, social functioning, role limitations due to emotional problems, and mental health. All scores are transformed into a 0100 scale on the assumption that each question carries equal weight. The scale was translated into Arabic and tested for validity by Hassan $(2014)(\mathrm{r}=0.86)^{(31)}$.

Tool III: Checklist to Identify Medication Side Effects

This tool was developed by the researchers reviewing current literature $\mathrm{r}^{(1,15,28)}$ and used to assess the common side effects associated with pegylated interferon and ribavirin therapy including: fatigue, sleep disturbance, weight loss, skin irritation, anorexia, muscle aches, headache, nausea, vomiting, diarrhea, mouth ulcer, eye irritation, and anxiety.

\section{Tool IV: Fatigue Severity Scale ${ }^{(32)}$}

It was adopted from Krupp (1989) and used to measure fatigue severity. It consists of nine statements; each statement is scored from 1 to 7 depending on the degree of fatigue, where 1 indicates strongly disagree (low fatigue level) and 7 indicates strongly agree (high fatigue level). The total score range from 9-72 and higher scores indicate higher level of fatigue.

Tool V: Nursing Interventions Program for Side Effects of Interferon and Ribavirin

The nursing interventions were developed by the researchers based on 
thorough review of current literature ${ }^{(1,24,33,34)}$. It includes the following:

- Disease process: definition, causes, signs and symptoms and drug used for treating HCV: name, dose, and route of administration and duration of treatment associated with the therapy.

- Common side effects: fatigue, insomnia, loss of appetite, bone ache, itching, nausea and vomiting.

- Nursing measures to overcome common side effects of $\mathrm{HCV}$ treatment.

- Stretching exercises (arms, hands and wrists and legs) and deep breathing exercises (pursed-lip breathing and diaphragmatic breathing).

\section{Method}

1. Permission to carry out the study was obtained from the responsible authorities.

2. The study tools I (Interview schedule sheet) and III (Checklist to Identify Medication Side Effects) were developed by the researchers after thorough review of current literature.

3. Tool IV (Fatigue Severity Scale) was translated into arabic and tested for reliability using Cronbach's coefficient alpha $r=0.86$. It was applied on 10 elderly patients with liver disease selected from outpatient clinic in General Mansoura Hospital.

4. Tool V (Nursing interventions for side effects of interferon and ribavirin therapy) was developed based on review of current literature. A booklet containing the content of the nursing intervention was designed by the researchers. It was written in arabic language and supplemented by pictures and illustrations to help the elderly patient to understand its content.
5. Study tools I, III, IV and V were revised by jury to ensure content validity. The jury consisted of 5 experts in Hepatology Medicine, Public Health, Geriatric Medicine, and Gerontological Nursing from Faculty of Nursing of Mansoura and Alexandria Universities.

6. A pilot study was carried out on 10 elderly patients receiving pegylated interferon and ribavirin selected from Specialized Medical Hospital outpatient clinics to test and ascertain the clarity, feasibility, applicability of the study tools and the necessary modifications were done accordingly. These elderly patients who included in the pilot study were excluded from the study sample.

7. The study subjects 66 were randomly assigned to two equal groups of 33 each. The control group received the hospital routine care and the experimental group was given both the nursing interventions program and the routine hospital care.

8. The required laboratory investigations such as (hemoglobin level, white blood cell count, platelets, Alanine amino transfers, and Asperate amino transfers) were done three times by the researchers at the hospitals lab before starting the treatment with interferon and ribavirin then 8 and 12 weeks in the morning while the elderly patients were fasting. The sample was collected by researchers and submitted to the laboratory technician for analysis.

9. Each study subject in both the experimental and the control groups was interviewed individually by the researcher in the waiting room of hospital outpatient clinic starting from 9 am to $1 \mathrm{pm}$ to collect the baseline elderly patients data. It was possible interview to 3-4 elderly patients daily for 3 days /week (Saturday, Tuesday 
and Wednesday) according to routine outpatient clinic in the hospital.

10. The proposed interventions were developed by the researchers based on reviewing the relevant literatures. It included educational and practices interventions with the aim of reducing the side effects of hepatitis C treatment. These interventions conducted in four consecutive sessions in the outpatient clinics, each session lasted from thirty to forty five minutes.

\section{Program implementation:}

- Before the start of these sessions, the researcher welcomed each elderly patient on admission, ensures that the patient is seated comfortably, introduced herself and explained the purpose of the study. Then a verbal consent from each study subject to participate in the study was obtained.

\section{1- Education of elderly patients with} HCV was carried out in two sessions:

- First session: included information about the disease process; definition, causes, mode of transmission of $\mathrm{HCV}$, signs and symptoms and drug used for treating HCV (name, dose, site of administration, duration of treatment associated with the therapy).

- A brief summary of the important points discussed was given and patients were allowed to ask questions.

- Second session: common side effects associated with pegylated interferon and ribavirin and nursing interventions:

a) Fatigue: Do not exhaust yourself, take rest between activities, take a warm shower, avoid smoking and take short naps not more than 20 minutes/day. b) Bone ache: Alternate application of hot and ice packs on the affected part, avoid prolonged periods of inactivity, and perform stretching exercises.

c) Itching: Use non irritant soap, try rubbing, or apply pressure instead of scratching, apply an ice cube on itching area, drink plenty of water, apply moisturizer immediately after shower as creams (Vaseline) and wear cotton cloths.

d) Insomnia: Sleep 6 to 8 hours at night daily, go to bed at the same time every night, perform deep breathing exercise daily, drink cup of milk before bedtime and decrease naps/day.

e) Fever: Remove layers of blankets and clothing, use of warm sponge bath, and increase fluid intake.

f) Dry cough: Stay hydrated and sips on water throughout the day and sucks on sugar-free hard candies and take cough drops.

g) Heart burn: Eat bland foods such as milk and yogurt and avoid spicy, fatty, sweet or highly acidic foods, avoid heavy meals and foods that cause gas such as broccoli, cauliflower, cabbage, beans and carbonated drinks, and don't lie down for a few hours after eating.

h) Anorexia and nausea: Eat smaller and more frequent meals; eat snacks that are high in protein and calories such as: cheese, eggs, nuts and lean meats and maintain good oral hygiene by brushing and flossing every day. 
i) Stomatitis: Gentle brushing the teeth, drink lots of water, don't drink liquid excessively hot, ice or frozen juice bars may soothe mouth sores, avoid eat foods that are hard crunchy, spicy, salty, or acidic as lemon and mango, sucking on sugar-free lemon candies can relieve a dry mouth and use mouth moisturizers such as Biotenex.

j) Eye irritation: Compliance with eye drop, take off glared light during sleep and avoid dust and itching in eyes.

k) Hair loss: Do not wash hair too frequently, use hat or scarf to protect hair from damage.

- In the educational sessions the researchers used large printed materials, one to one instruction, power point presentation and discussion.

- At the end of these sessions the researchers gave a brief summary of the important points then they asked specific questions about the topic to make sure of the patient understanding and reinforcement of vague points were done.

\section{2- Practical sessions: were carried out in 2 sessions.}

- Before starting these sessions; elderly patients were asked questions related to the topic discussed in the previous two sessions to identify their understanding; misses or unclear points were re-emphasized by the researchers.

- First session: During this session, elderly patients were trained to practice two types of deep breathing exercises (pursed-lip breathing and diaphragmatic breathing) to reduce fatigue and anxiety. These types of exercises were performed 10 times, every 4 hours daily. a) The researchers instructed the elderly patients to perform pursed - lip breathing when they are relaxed by taking a slow, deep inspiration (lasting at least 3 seconds) through the nose, followed by prolonged expiration through pursed lips (lasting at least 6 seconds). The researchers emphasized that a soft whistling sound is made during exhalation if pursed - lip breathing is performed correctly.

b) For diaphragmatic breathing, the researchers taught the elderly patients place one hand on the abdomen and one hand lightly on the chest and breath in. The researchers emphasized that with proper diaphragmatic breathing, the hand on the abdomen moves up on inspiration.

- Second session: During this session, patients were trained to practice stretching exercises for the arms, hands, wrists, legs (front and back) and ankles to reduce the intensity of bone ache.

The researchers instructed the elderly patients to perform these exercises while they are sitting or standing for 8 to 15 times daily.

Teaching methods followed in the previous sessions included demonstration by the researchers and redemonstration by the elderly patients. Each elderly patient was asked to practice the taught exercise under the research supervision.

Other teaching materials included illustrated picture, and stretching exercises videos. The instructional booklet developed by the researchers was given to each patient to help him review the given information.

Telephone calls were provided once/ week during four weeks after the completion nursing intervention 
program for the elderly patients in the experimental group to check practice of the required exercise and identify side effects and measures applied to overcome them. Problems and concerns in performing the activities were discussed.

\section{Evaluation of the program:}

Reassessment of each study subject was done three times to evaluate the effect of the proposed nursing interventions. The first reassessment was done 4 weeks after the start of hepatitis $\mathrm{C}$ treatment and the second after 8 weeks and the third after 12 weeks of the program using tools (I $(2, b)$, II, III, IV).

Data collection covered a period of 15 months from April 2013 to October 2014.

\section{Ethical considerations:}

A verbal consent from the study subjects to participate in the study was obtained after explanation of the study purpose. Privacy, confidentiality, anonymity and the right to withdraw any time was assured

\section{Statistical Analysis}

Data was analyzed using SPSS (Statistical Package for Social Sciences) version 15. Data was presented as number and percent. Comparison between groups was done by Chi-Square test. Normally distributed data was presented as mean \pm SD. Paired t-test was used for comparison within groups. Student t-test was used to compare between two groups. Wilcoxon singed ranks test was used for comparison within group. $\mathrm{P}<0.05$ was considered to be statistically significant.

\section{Results}

Table (1) shows the socio-demographic characteristics of the experimental and control groups. The age of the majority of the experimental and control groups ranged from 60 to less than 65 years $(66.7 \%$ and $75.8 \%$ respectively), with a mean age of
$63.7 \pm 3.29$ years for those in the experimental group and $63.06 \pm 2.45$ years for those in the control group with no statistical significant difference between the two groups $(\chi 2=0.721, \mathrm{P}=0.697)$. Males were more prevalent in the studied sample, they constituted $(75.8 \%)$ of the experimental group, and $(69.7 \%)$ of the control group, with no significant difference between the two groups $(\chi 2=0.306$, $\mathrm{P}=0.580)$. The majority of the experimental and control groups $(63.6 \%$ and $57.6 \%$ respectively) were married with no significant difference between the two groups $(\chi 2=1.629, \mathrm{P}=0.653)$. No statistical significant difference is observed regarding the level of education and occupation before retirement of the two groups $(\chi 2=5.225$, $\mathrm{P}=0.156, \chi 2=1.886, \mathrm{P}=0.865$ respectively). Concerning the living arrangement, no observed statistical significant difference between the two groups $(\chi 2=0.361$, $\mathrm{P}=0.986$ ), where living with family was prevailing among $78.8 \%$ and $72.7 \%$ of the experimental and control groups respectively. The monthly income reported by the experimental and control group was enough with no significant differences between them $(\chi 2=4.977, \mathrm{P}=0.026)$.Pension was the main source of income with no significant differences were detected between two groups $(\chi 2=1.964, \mathrm{P}=0.375)$.

Table (2) shows the medical condition of the experimental and control groups. It is noted that, more than three quarters of the experimental and control groups had hepatitis $\mathrm{C}$ virus since more than one year $(75.8 \%$ and $78.8 \%$ respectively). No significant difference between the experimental and control groups regarding duration of hepatitis $\mathrm{C}(\chi 2=0.086, \mathrm{P}=0.769)$. As regards co morbidities, the table reveals that, more than two fifth $(45.5 \%)$ of the experimental group and more than two thirds $(36.4 \%)$ of the control group had three to five medical diseases such as hypertension, diabetes mellitus and osteoarthritis. Neither the number of medications nor the number of medical diseases differed significantly between the 
study and control groups $(\chi 2=0.263$, $\mathrm{P}=0.877 \quad$ and $\quad \chi 2=0.725, \quad \mathrm{P}=0.696$ respectively). Concerning number of medication, this table shows that, $33.3 \%$ and $39.4 \%$ of the experimental and control groups respectively used one to two medications other than hepatitis C medications such as antihypertensive medication, diabetic agent and analgesics. More than one third of experimental and control group $(36.4 \%$ and $33.3 \%$ respectively) reported using more than five medications.

Figure (1) illustrates the common side effects of interferon and ribavirin of elderly patients in experimental and control groups. It is evident that fatigue and bone ache were the main presenting side effects of interferon and ribavirin for elderly patients in experimental of control groups where fatigue reported by $(100 \%$ of each of the two groups and $93.9 \%$ and $94.0 \%$ for experimental and control group). This was followed by itching $(87.9 \%$ for each group). Insomnia was reported by $(81.8 \%$ and $57.9 \%$ ) of experimental and control groups respectively, fever reported by $81.8 \%$ for each, and dry cough by $(78.8 \%$ of experimental group and $81.9 \%$ of control group). Heart burn, anorexia, and nausea were reported by $(79.7 \%, 72.8 \%, 66.7 \%$ respectively) of experimental group and $(79.7 \%, 72.7 \%, 69.7 \%$ respectively) of control group, while eye irritation, stomatitis and sexual problem were reported by $(54,6 \%, 48.5 \%, 36.3$ respectively) of experimental group and $(66.6 \%, 48.5 \%$, $36.3 \%$ ) of control group. There were no significant differences between the two groups as regards side effects of interferon and ribavirin.

Table (3) reveals the effect of nursing intervention on major side effects of interferon and ribavirin with respect to the experimental and control groups. It appears from the table that the elderly patients in the experimental group showed significant improvement in their rating of perceived fatigue at both 8 and 12 weeks post intervention, while fatigue level for those in the control group did not show any significant change in both evaluations. In addition, 8 and 12 weeks post intervention fatigue level was significantly different between experimental and control groups where $\mathrm{P}$ value was found to be 0.016 and 0.000 respectively. Moreover, all other side effects improved significantly in the experimental group after applying nursing intervention than in the control group. It should be pointed out that, most major side effects showed statistically significant differences between experimental and control groups after 8 and 12 weeks of nursing intervention were itching, insomnia, anorexia and heart burn where $\mathrm{P}$ values were found to be $0.046,0.025,0.005$ and 0.012 respectively after 12 weeks of nursing intervention.

Table (4) illustrates the impact of nursing intervention on minor side effects of interferon and ribavirin with respect to the experimental and control groups. Elderly patients in the experimental group showed statistically significant improvement in all minor side effects observed at 8 and 12 weeks post nursing intervention, while no significant change was observed in the control group. The differences between the two groups regarding nausea, eye irritation, stomatitis and anxiety were statistically significant where $\mathrm{p}$ values were found to be $0.012,0.050,0.000$ and 0.004 respectively.

Table (5) illustrates the results of laboratory investigations of the experimental and control groups pre and post nursing intervention. Although, all the results of laboratory investigations decreased significantly at 8 weeks after the treatment in both groups, significant improvement was detected in the experimental group at 12 weeks of nursing intervention regarding hemoglobin, WBCs and SGOT level where $\mathrm{p}$ values were found to be $0.001,0.046$, and 0.025 respectively. In addition, 12 weeks post nursing intervention all results of laboratory investigation were significantly different in 
the study and control groups except for SGOT and SGPT.

Table (6) reveals the results of applying SF-36 to assess the QOL of the experimental and control groups pre and post nursing intervention. It appears from the table that, the scores for all dimensions of QOL improved significantly in the study group at 8 weeks post intervention and the improvement was maintained at 12 weeks, whereas patients in the control group had significant decreased scores and lower values for all dimension of QOL except for role limitation due to physical health and role limitation due to emotional problems. The differences between the two groups were statistically significant, at both 8 and 12 week post intervention for all dimensions of QOL.

\section{Discussion}

The number of elderly patients with chronic hepatitis $\mathrm{C}$ is currently increasing in Egypt and other countries. Unfortunately, because of the increased prevalence of hepatitis $\mathrm{C}$ virus and the associated cirrhosis and mortality, treatment is an important issue which may be carried out by a combination of drug therapy of interferon and ribavirin. The adverse side effects of these drugs among elderly are not rare because they could be managed effectively which has great impact on patient quality of life during the course of treatment. Therefore this study aimed to identify the effect of nursing intervention for hepatitis $\mathrm{C}$ elderly patients to reduce the side effects of interferon and ribavirin and improve their quality of life.

The present study revealed that the mean age of the studied patients with hepatitis $\mathrm{C}$ and their controls was 63 years and the study males were more prevalent; this may be because men are more likely to be exposed to risk factors to HCV. More than half of the studied sample was married. Also, nearly half of the patients had a bachelor degree or higher education (table
1). This is in accordance with other studies in Japan and England by Bianchi et al., $(2000)^{(35)}$, Arase et al., $(2007)^{(36)}$ and Koyama et al (2006) ${ }^{(37)}$ who revealed that the mean age of their studied subjects was 63 years and the majority of them had secondary and higher education degree. In the same line, in Italy a study carried out by Terranova and Luca (1999) ${ }^{(38)}$ concluded that the hepatitis $\mathrm{C}$ elderly males were more than females and aged 60 to 72 . While in Thailand a study carried out by Sobhonslidsuk et al., $(2006)^{(39)}$ reported that the majority of patients in both groups were males and had education lower than bachelor's degree.

\section{Side effects of Pegylated interferon and Ribavirin:}

Fatigue is perhaps the most common side effects reported among patients with chronic hepatitis $\mathrm{C}$ as a troublesome side effect of the therapy (Kallman, 2007) ${ }^{(40)}$. The finding of this study revealed that all study samples suffered from severe fatigue as adverse events from hepatitis $\mathrm{C}$ therapy (figure 1, table 3). Moreover, the elderly patients in the experimental group showed significant improvement in their ratings of perceived fatigue at both 8 and 12 weeks of nursing intervention, while fatigue level for those in the control group did not show any significant change at 8 and 12 weeks (figure 1 and table 3 ). These results were in accordance with a study in Menofyia by Heneedy (2009) ${ }^{(41)}$ who found that fatigue decreased among the study group than the control group after giving the nursing intervention. In the same line Mohsen $(2011)^{(33)}$ reported that all the studied subjects had severe fatigue before giving the intervention but after 8 weeks, more than one fourth of the sample had mild fatigue and more than half had moderate level of fatigue. A study carried out in USA by Sarker et al., (2012) ${ }^{(42)}$ concluded that half of patients enrolled in a study of antiviral therapy of $\mathrm{HCV}$ admitted that they had some degree of fatigue, of which two-thirds rated it as moderate or severe and this 
significantly improved among those who achieved viral eradication.

The current study revealed that, more than half of study subjects reported that the major side effects of treatment were bone ache, itching, insomnia, fever, dry cough, heart burn, and anorexia before giving the proposed nursing intervention. While after 8 and 12 weeks, there was a significant decrease in the number of patients complaining from these side effects in experimental group more than in the control group (Table 3). This may be attributed to the educational sessions that were provided to cover all aspects of hepatitis $\mathrm{C}$ virus (definition, causes, signs and symptoms, treatment, action, side effects and how to deal with them) which eventually increased elders coping. This result supports those of Seyam et al., $(2005)^{(43)}$ in UK who revealed that, most elderly suffered from dry cough, fever, bone ach, itching, and fatigue also another study in Germany by Huang et al., $(2010)^{(44)}$ reported that most elderly patients with hepatitis $\mathrm{C}$ infection had greater adverse events which can be minimized following care regimen such as taking warm shower to relieve itching. In keeping with the literature on the topic, fever, dry cough, itching, and fatigue were reported as the most common side effects of $\mathrm{HCV}$ treatment (Zucker and Miller, 2001) ${ }^{(17)}$. Sleeping difficulties highly feature in several studies (Mulhall and Younossi, 2005; Zucker and Miller, 2001) ${ }^{(17,45)}$.

The study results are in accordance with studies in Egypt by Mohsen et al., $(2011)^{(33)}$, Fareed $(2004)^{(46)}$ and Elshikh $(2003)^{(47)}$ who evaluated the effect of nursing management protocol on selected side effects of interferon and ribavirin among hepatitis $\mathrm{C}$ patients and concluded that there was significant improvement in patients knowledge which lead to reducing the side effects of interferon and ribavirin post 8 weeks of nursing intervention. Study in USA by Fried (2002) ${ }^{(34)}$ reported that the side effects of hepatitis $C$ therapy were reduced to their minimal levels after giving the patients health education before the beginning of treatment. In addition, Study in London by Grogan and Timmins $(2007)^{(5)}$ reported that the high scoring side effect was sexual dysfunction of elderly patients receiving interferon and ribavirin while in the present study it was only claimed by a small percent. This discrepancy, in relation to sexual problem (table 4), may be attributed to culture where for Egyptian males it is difficult to admit sexual problems, as it is considered a stigma against their masculinity.

\section{Laboratory investigations:}

The results of laboratory investigations decreased significantly at 8 weeks after the treatment in the experimental and control groups (table 5). This is accordance with a study in Iran by Lankarani $(2004)^{(24)}$ who mentioned that anemia and thrombocytopenia were the most significant hematological side effects of combination therapy in which there is usually a drop of approximately $2-3 \mathrm{~g} / \mathrm{dl}$ of hemoglobin level and $10-50 \%$ of platelet count. Moreover, findings of the present study showed significant improvement in hemoglobin level, white blood cells count and SOGT after application of the proposed nursing intervention. This is in agreement with study in Menofyia by Heneedy (2009) ${ }^{(41)}$ who stated that nursing intervention for patients with liver diseases has a number of positive effects on physical responses including laboratory findings. In the same line Alavian et al., $(2006)^{(48)}$ showed that the mean Asperate and Alanine Aminotransferse were decreased after patient education and this alteration was significant. The same results were confirmed in a study in Iran by PeckRadosavljevic (2002) ${ }^{(21)}$ who found that, lower hemoglobin level was the most common laboratory abnormalities especially post four week of treatment and the return to normal value with decreased dose of ribavirin within 12 weeks of hepatitis $\mathrm{C}$ therapy and follow the treatment regimen for anemia. In the same direction a study 
conducted in Italy by Terranova and Luca, $(1999)^{(38)}$ reported that there was significant changes in hemoglobin, platelet and leukocytes during treatment and returned to normal level post 12 week of treatment.

\section{Health Related Quality of Life:}

In the present study SF-36 health survey questionnaire was used to assess the QOL of the experimental and control groups before and after 8 and 12 weeks of nursing intervention, the total scores for all dimensions of QOL namely; physical functioning, role limitation due to physical health, pain, general health, vitality, social functioning, role limitation due to emotional problems and emotional wellbeing improved significantly in the study group at 8 weeks post nursing intervention and the improvement was maintained at 12 weeks.(table 6). This result is in harmony with other studies in Greece by Bonkovsky and Woolley (1999) who reported that significant improvement in quality of life post nursing intervention in the study group, while the control group didn't show any improvement in quality of life and in adherence with the therapeutic regimen ${ }^{(49)}$. Another study in China by Chao Kang et al., $(2005)^{(50)}$ stated that, patients who received antiviral treatment and follow the adherence with treatment regimen, all had significant higher mean HRQOL scores in all SF-36 domains at the $12^{\text {th }}$ weeks of treatment as compared with pretreatment values, but the mean scores of the control group were lower post $12^{\text {th }}$ weeks of treatment.

\section{Conclusion}

Based on the present study findings, it can be concluded that the more prevalent side effects of hepatitis $\mathrm{C}$ treatment among the experimental group were fatigue, insomnia, fever, dry cough, bone ache, itching, and stomatitis before implementing the nursing intervention program. Side effects and quality of life mean scores improved significantly in the study group compared to control group after 8 and 12 weeks of nursing intervention. As well, the total laboratory investigations, depression and fatigue scores of elderly patients in the study group significant improved after applying the nursing intervention than control group.

\section{Recommendations}

Based on the results of the present study, the following recommendations are suggested:

- Family members and/ or significant others should be involved in planning the care for elderly patients with hepatitis $\mathrm{C}$ so that they can support and encourage them to manage the occurrence of side effects.

- Mass media can play a vital role in providing the public with information about common side effects of pegylated interferon and ribavirin and measures to overcome them.

- Further studies with a large number of elderly patients are needed to confirm these findings and long-term follow up to evaluate the effectiveness of nursing intervention.

\section{Acknowledgment}

The authors would like to thank the elderly patients who participated in this study; we greatly appreciate the support of all nursing and medical staff working at Specialized Medical Hospital, General Mansoura Hospital and Egyptian Liver Hospital in Dakahlia Governorate. 
Table (1): Socio-demographic Characteristics of the Experimental and Control groups.

\begin{tabular}{|c|c|c|c|c|c|}
\hline \multirow{2}{*}{ Items } & \multicolumn{2}{|c|}{$\begin{array}{l}\text { Experimental } \\
\text { group }\end{array}$} & \multicolumn{2}{|c|}{ Control group } & \multirow{2}{*}{$\begin{array}{l}\text { Pearson } \\
\text { Chi- } \\
\text { Square } \chi^{2} \\
\text { test } \\
\text { (P) }\end{array}$} \\
\hline & $\mathrm{N}=(33)$ & $\%$ & $\begin{array}{l}\mathrm{N}= \\
(\mathbf{3 3})\end{array}$ & $\%$ & \\
\hline $\begin{array}{l}\text { Age (in years) } \\
60- \\
65- \\
70+ \\
\end{array}$ & $\begin{array}{c}22 \\
10 \\
1 \\
\end{array}$ & $\begin{array}{c}66.7 \\
30.3 \\
3.0 \\
\end{array}$ & $\begin{array}{c}25 \\
7 \\
1 \\
\end{array}$ & $\begin{array}{r}75.8 \\
21.2 \\
3.0 \\
\end{array}$ & 0.721 \\
\hline Mean \pm SD & \multicolumn{2}{|c|}{$63.7 \pm 3.29$} & \multicolumn{2}{|c|}{$63.06 \pm 2.45$} & \\
\hline $\begin{aligned} & \text { Sex } \\
& \text { - } \text { Male } \\
& \text { - } \text { female } \\
&\end{aligned}$ & $\begin{array}{c}25 \\
8 \\
\end{array}$ & $\begin{array}{l}75.8 \\
24.2 \\
\end{array}$ & $\begin{array}{l}23 \\
10 \\
\end{array}$ & $\begin{array}{l}69.7 \\
30.3 \\
\end{array}$ & $\begin{array}{c}0.306 \\
(0.580)\end{array}$ \\
\hline $\begin{array}{cl}\text { Marital status } \\
\text { - } & \text { Married } \\
\text { - } & \text { Divorced } \\
\text { - } & \text { Widow } \\
\text { - } & \text { Single } \\
\end{array}$ & $\begin{array}{c}21 \\
7 \\
4 \\
1 \\
\end{array}$ & $\begin{array}{c}63.6 \\
21.2 \\
12.1 \\
3.0\end{array}$ & $\begin{array}{l}19 \\
10 \\
2 \\
2 \\
\end{array}$ & $\begin{array}{c}57.6 \\
30.3 \\
6.1 \\
6.1 \\
\end{array}$ & $\begin{array}{c}1.629 \\
(0.653)\end{array}$ \\
\hline $\begin{array}{l}\text { Educational level } \\
\text { - Read and write } \\
\text { - Technical education } \\
\text { - University education } \\
\text { - Higher education }\end{array}$ & $\begin{array}{c}3 \\
12 \\
14 \\
4\end{array}$ & $\begin{array}{c}9.1 \\
36.4 \\
42.4 \\
12.1\end{array}$ & $\begin{array}{c}5 \\
16 \\
12 \\
0\end{array}$ & $\begin{array}{c}15.2 \\
48.5 \\
36.4 \\
0\end{array}$ & $\begin{array}{c}5.225 \\
(0.156)\end{array}$ \\
\hline $\begin{array}{l}\text { Occupation before retirement : } \\
\text { - Employee } \\
\text { - Policeman } \\
\text { - House wife } \\
\text { - Doctors } \\
\text { - Free business } \\
\end{array}$ & $\begin{array}{l}17 \\
7 \\
4 \\
4 \\
1 \\
\end{array}$ & $\begin{array}{c}51.5 \\
21.2 \\
12.1 \\
12.1 \\
3.0 \\
\end{array}$ & $\begin{array}{c}17 \\
6 \\
7 \\
2 \\
1 \\
\end{array}$ & $\begin{array}{c}51.5 \\
18.2 \\
21.2 \\
6.1 \\
3.0 \\
\end{array}$ & $\begin{array}{c}1.886 \\
(0.865)\end{array}$ \\
\hline $\begin{array}{l}\text { Living arrangement: } \\
\text { - With family } \\
\text { - Alone }\end{array}$ & $\begin{array}{c}26 \\
7\end{array}$ & $\begin{array}{l}78.8 \\
21.2\end{array}$ & $\begin{array}{c}9 \\
24\end{array}$ & $\begin{array}{l}72.7 \\
27.3\end{array}$ & $\begin{array}{c}0.361 \\
(0.986)\end{array}$ \\
\hline $\begin{array}{l}\text { Monthly income } \\
\text { - Enough } \\
\text { - Not enough } \\
\end{array}$ & $\begin{array}{c}25 \\
8\end{array}$ & $\begin{array}{l}75.7 \\
24.3\end{array}$ & $\begin{array}{l}17 \\
16\end{array}$ & $\begin{array}{l}51.5 \\
48.5\end{array}$ & $\begin{array}{c}4.977 \\
(0.026)\end{array}$ \\
\hline $\begin{array}{c}\text { Source of income } \\
\text { - Pension } \\
\text { - Sons } \\
\text { - } \text { Free work } \\
\end{array}$ & $\begin{array}{c}26 \\
4 \\
3 \\
\end{array}$ & $\begin{array}{c}78.8 \\
12.1 \\
9.1 \\
\end{array}$ & $\begin{array}{c}29 \\
1 \\
3 \\
\end{array}$ & $\begin{array}{c}87.9 \\
3.0 \\
9.1 \\
\end{array}$ & $\begin{array}{c}1.964 \\
(0.375)\end{array}$ \\
\hline
\end{tabular}

*Significant at $\mathrm{P} \leq 0.05$ 
Table (2): Medical History of the Experimental and Control groups.

\begin{tabular}{|c|c|c|c|c|c|}
\hline \multirow{2}{*}{ items } & \multicolumn{2}{|c|}{$\begin{array}{c}\text { Experimental } \\
\text { group }\end{array}$} & \multicolumn{2}{|c|}{ Control group } & \multirow{2}{*}{$\begin{array}{c}\text { Pearson } \\
\text { Chi-Square } \\
\chi^{2} \text { test } \\
\text { (P) }\end{array}$} \\
\hline & $\begin{array}{l}\mathrm{N}= \\
(33)\end{array}$ & $\%$ & $\begin{array}{l}\mathrm{N}= \\
(33)\end{array}$ & $\%$ & \\
\hline \multicolumn{6}{|l|}{ Duration of hepatitis C virus: } \\
\hline More than one year & 25 & 75.8 & 26 & 78.8 & 0.086 \\
\hline Less than one year & 8 & 24.2 & 7 & 21.2 & $(0.769)$ \\
\hline \multicolumn{6}{|l|}{ Co morbidities further than HCV: } \\
\hline $1-2$ & 10 & 30.3 & 13 & 39.4 & \multirow{3}{*}{$\begin{array}{c}0.725 \\
(0.696)\end{array}$} \\
\hline $3-5$ & 15 & 45.5 & 12 & 36.4 & \\
\hline $5+$ & 8 & 24.2 & 8 & 24.2 & \\
\hline \multicolumn{6}{|l|}{ Number of Medications used: } \\
\hline $1-2$ & 11 & 33.3 & 13 & 39.4 & \multirow{3}{*}{$\begin{array}{c}0.263 \\
(0.877)\end{array}$} \\
\hline $3-5$ & 10 & 30.3 & 9 & 27.3 & \\
\hline $5+$ & 12 & 36.4 & 11 & 33.3 & \\
\hline
\end{tabular}

*Significant at $\mathrm{P} \leq 0.05$ 


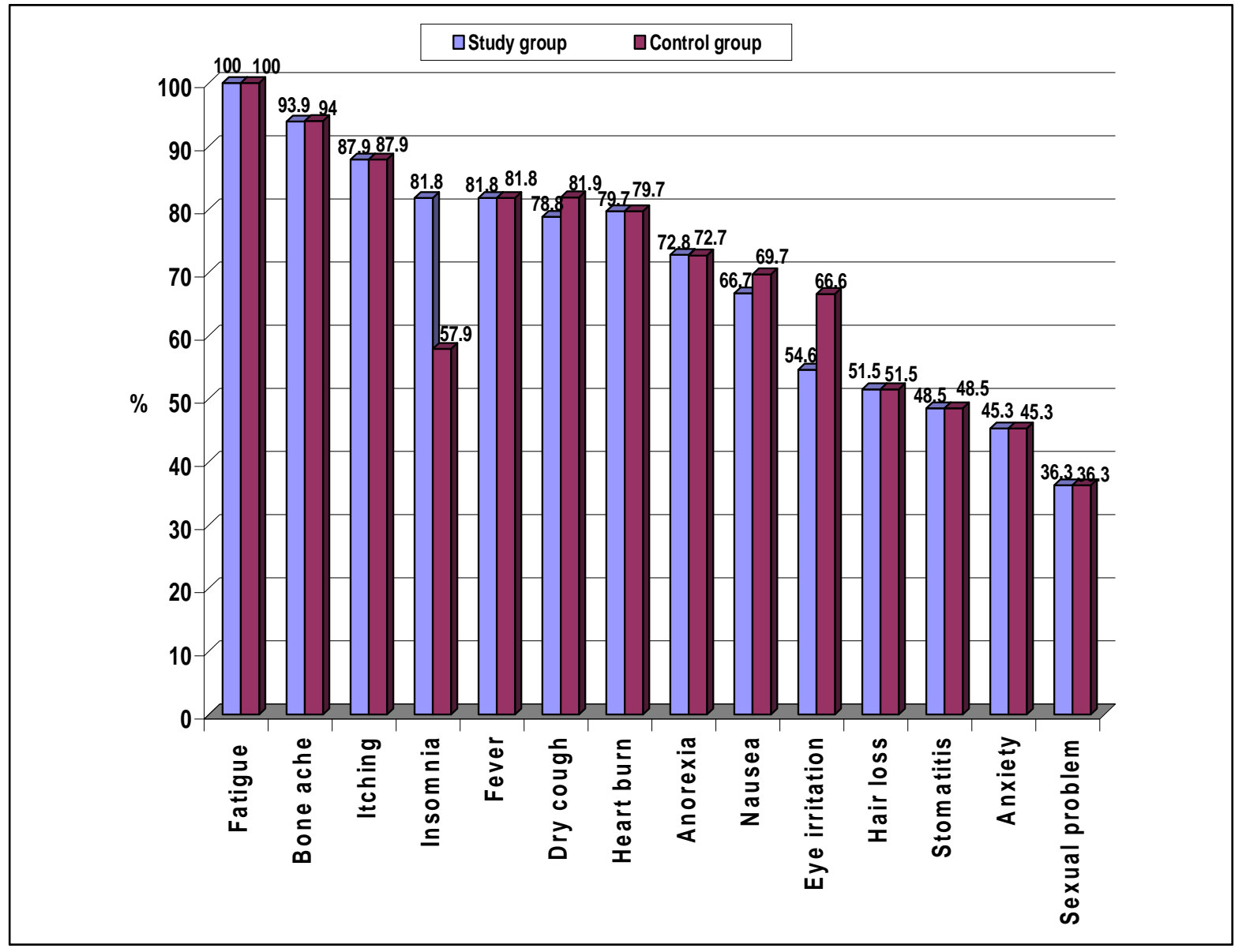

Figure (1): Common Side Effects of Interferon and Ribavirin of Elderly Patients in Experimental and Control Groups. 
Table (3): Effect of Nursing Intervention on Major Side Effects of Interferon and Ribavirin among the Experimental and Control groups.

\begin{tabular}{|c|c|c|c|c|c|c|c|c|c|}
\hline \multirow{3}{*}{ Items } & \multicolumn{3}{|c|}{$\begin{array}{c}\text { Experimental group } \\
\mathbf{N}=\mathbf{3 3} \\
\end{array}$} & \multicolumn{3}{|c|}{$\begin{array}{c}\text { Control group } \\
\mathrm{N}=\mathbf{3 3} \\
\end{array}$} & \multicolumn{3}{|c|}{$\begin{array}{c}\text { Test of significance } \\
(\mathbf{P})\end{array}$} \\
\hline & 4/W & 8/W & $12 / \mathrm{W}$ & 4/W & $8 / \mathrm{W}$ & $12 / \mathrm{W}$ & \multirow{2}{*}{$\begin{array}{c}\chi^{2} \\
\text { Test }(P)^{a} \\
\end{array}$} & \multirow{2}{*}{$\begin{array}{c}\chi^{2} \\
\text { Test }(P)^{b} \\
\end{array}$} & \multirow{2}{*}{$\begin{array}{c}\chi^{2} \\
\text { Test }(P)^{c}\end{array}$} \\
\hline & $\%$ & $\%$ & $\%$ & $\%$ & $\%$ & $\%$ & & & \\
\hline $\begin{array}{l}\text { Fatigue } \\
\text { - Moderate } \\
\text { - Severe }\end{array}$ & $\begin{array}{c}6.1 \\
93.9\end{array}$ & $\begin{array}{l}33.3 \\
66.7\end{array}$ & $\begin{array}{l}60.6 \\
39.4\end{array}$ & $\begin{array}{c}6.1 \\
93.9\end{array}$ & $\begin{array}{c}9.1 \\
90.9\end{array}$ & $\begin{array}{c}6.1 \\
93.9\end{array}$ & \multirow[t]{4}{*}{$\begin{array}{c}0.000 \\
(1.000)\end{array}$} & \multirow[t]{4}{*}{$\begin{array}{c}5.802 \\
(0.016)^{*}\end{array}$} & \multirow[t]{4}{*}{$\begin{array}{c}22.091 \\
(0.000)^{*}\end{array}$} \\
\hline \multirow{3}{*}{$\begin{array}{l}Z \text { Test }(P)^{1} \\
Z \text { Test }(P)^{2} \\
Z \text { Test }(P)^{3}\end{array}$} & \multicolumn{3}{|c|}{$3.000(0.003)^{*}$} & \multicolumn{3}{|c|}{$1.000 \quad(0.317)$} & & & \\
\hline & \multirow{2}{*}{\multicolumn{3}{|c|}{$\begin{array}{cc}4.243 & (0.000)^{*} \\
3.000 & (0.003)^{*}\end{array}$}} & \multicolumn{3}{|c|}{$0.000 \quad(1.000)$} & & & \\
\hline & & & & \multicolumn{3}{|c|}{$1.000 \quad(0.317)$} & & & \\
\hline $\begin{array}{l}\text { Bone ache } \\
\text { - No }\end{array}$ & 6.1 & 3.0 & 21.2 & 6.1 & 3.0 & 21.2 & 0.106 & 3.900 & 3.914 \\
\hline - Mild & 33.3 & 60.6 & 57.6 & 30.3 & 39.4 & 36.4 & $(0.991)$ & $(0.272)$ & $(0.271)$ \\
\hline - Moderate & 36.4 & 33.3 & 15.2 & 36.4 & 45.5 & 30.3 & & & \\
\hline - Severe & 24.2 & 3.0 & 6.1 & 27.3 & 12.1 & 12.1 & & & \\
\hline$Z \operatorname{Test}(P)^{I}$ & \multicolumn{3}{|c|}{ (0.006)* } & \multicolumn{3}{|c|}{$1.732 \quad(0.083) *$} & & & \\
\hline$Z \operatorname{Test}(P)^{2}$ & \multicolumn{3}{|c|}{2.744} & \multicolumn{3}{|c|}{$2.993 \quad(0.003) *$} & & & \\
\hline$Z \operatorname{Test}(P)^{3}$ & \multicolumn{3}{|c|}{$(0.025) *$} & \multicolumn{3}{|c|}{$2.400 \quad(0.016) *$} & & & \\
\hline Itching & 121 & 33. & 303 & 121 & 303 & 273 & & & \\
\hline - Mild & 18.2 & 39.4 & 51.5 & 18.2 & 18.2 & 27.3 & 0.000 & 5.093 & 7.985 \\
\hline - Moderate & 39.4 & 21.2 & 18.2 & 39.4 & 39.4 & 33.3 & $(1.000)$ & $(0.165)$ & $(0.046)^{*}$ \\
\hline - Severe & 30.3 & 6.1 & 0.0 & 30.3 & 12.1 & 12.1 & & & \\
\hline$Z_{Z \text { Test }(P)^{I}}$ & \multicolumn{3}{|c|}{ 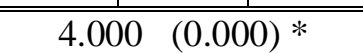 } & \multicolumn{3}{|c|}{$3.307 \quad(0.001) *$} & & & \\
\hline$Z$ Test $(P)^{2}$ & \multicolumn{3}{|c|}{$4.456(0.000) *$} & \multicolumn{3}{|c|}{$3.442(0.001) *$} & & & \\
\hline$Z$ Test $(P)^{3}$ & & $65(0.2$ & & & $8 \quad(0$. & & & & \\
\hline Insomnia & & & & & & & & & \\
\hline - No & 18.2 & 9.1 & 15.2 & 6.1 & 6.1 & 9.1 & 4.852 & 3.358 & 9.315 \\
\hline - Mild & 9.1 & 36.4 & 54.5 & 3.0 & 18.2 & 27.3 & $(0.183)$ & $(0.340)$ & $(0.025)^{*}$ \\
\hline - Moderate & 30.3 & 42.4 & 30.3 & 15.5 & 57.6 & 51.5 & & & \\
\hline - Severe & 42.4 & 0.0 & 12.1 & 39.4 & 18.2 & 12.1 & & & \\
\hline$\overline{Z Z \text { Test }(P)^{I}}$ & & $2(0.0$ & & & $7(0.0$ & & & & \\
\hline$\overline{Z \text { Test }(P)^{2}}$ & & $2(0.0$ & & & $5 \quad(0.1$ & & & & \\
\hline$Z$ Test $(P)^{3}$ & & $8(0.0$ & & & $41(0.1$ & & & & \\
\hline Fever & & & & & & & & & \\
\hline - No & 18.2 & 15.2 & 21.2 & 18.2 & 15.2 & 18.2 & 0.000 & 7.179 & 3.795 \\
\hline - Mild & 42.4 & 54.5 & 48.5 & 42.4 & 24.2 & 30.3 & (1.000) & $(0.066)$ & $(0.284)$ \\
\hline - Moderate & 39.4 & 27.3 & 21.2 & 39.4 & 54.5 & 42.4 & & & \\
\hline - Severe & 0.0 & 3.0 & 9.1 & 0.0 & 6.1 & 9.1 & & & \\
\hline$\overline{Z \text { Test }(P)^{l}}$ & & $\overline{9(0.0}$ & & 3.8 & (0.) & ) * & & & \\
\hline$Z$ Test $(P)^{2}$ & & $3(0.0$ & & & $3(0.0$ & & & & \\
\hline$Z$ Test $(P)^{3}$ & & $2(0.9$ & & & $2 \quad(0$ & & & & \\
\hline
\end{tabular}


Table (3) (Continued): Effect of Nursing Intervention on Major Side Effects of Interferon and Ribavirin among the Experimental and Control groups.

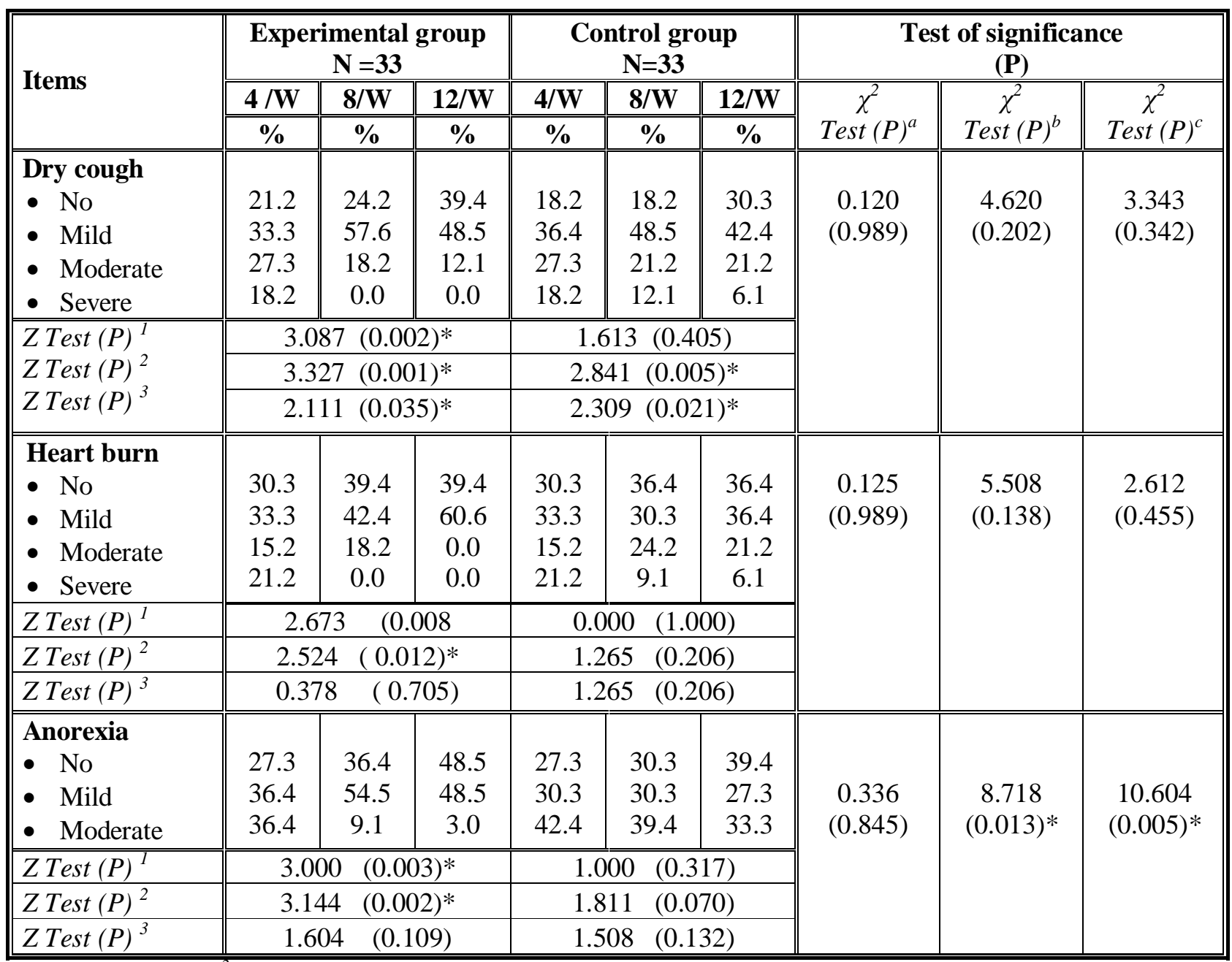

Pearson Chi-Square $\chi^{2}(P)^{a}$ : comparing experimental and control groups 4 week post intervention.

Pearson Chi-Square $\chi^{2}(P) b$ : comparing experimental and control groups 8 week post intervention.

Pearson Chi-Square $\chi 2(P)$ : comparing experimental and control groups 12 week post intervention.

Wilcoxon Signed Ranks $Z$ Test $(P)$ 1: comparing 4 and 8 week in each group.

Wilcoxon signed ranks $z$ test $(p)^{2}$ : comparing 4 and 12 week in each group.

Wilcoxon signed ranks $z$ test $(p)^{3}$ : comparing 8 and 12 week in each group.

*Significant at $\mathrm{P} \leq 0.05$.

W: week. 
Table (4): Effect of Nursing Intervention on Minor Side Effects of Interferon and Ribavirin among the Experimental and Control groups.

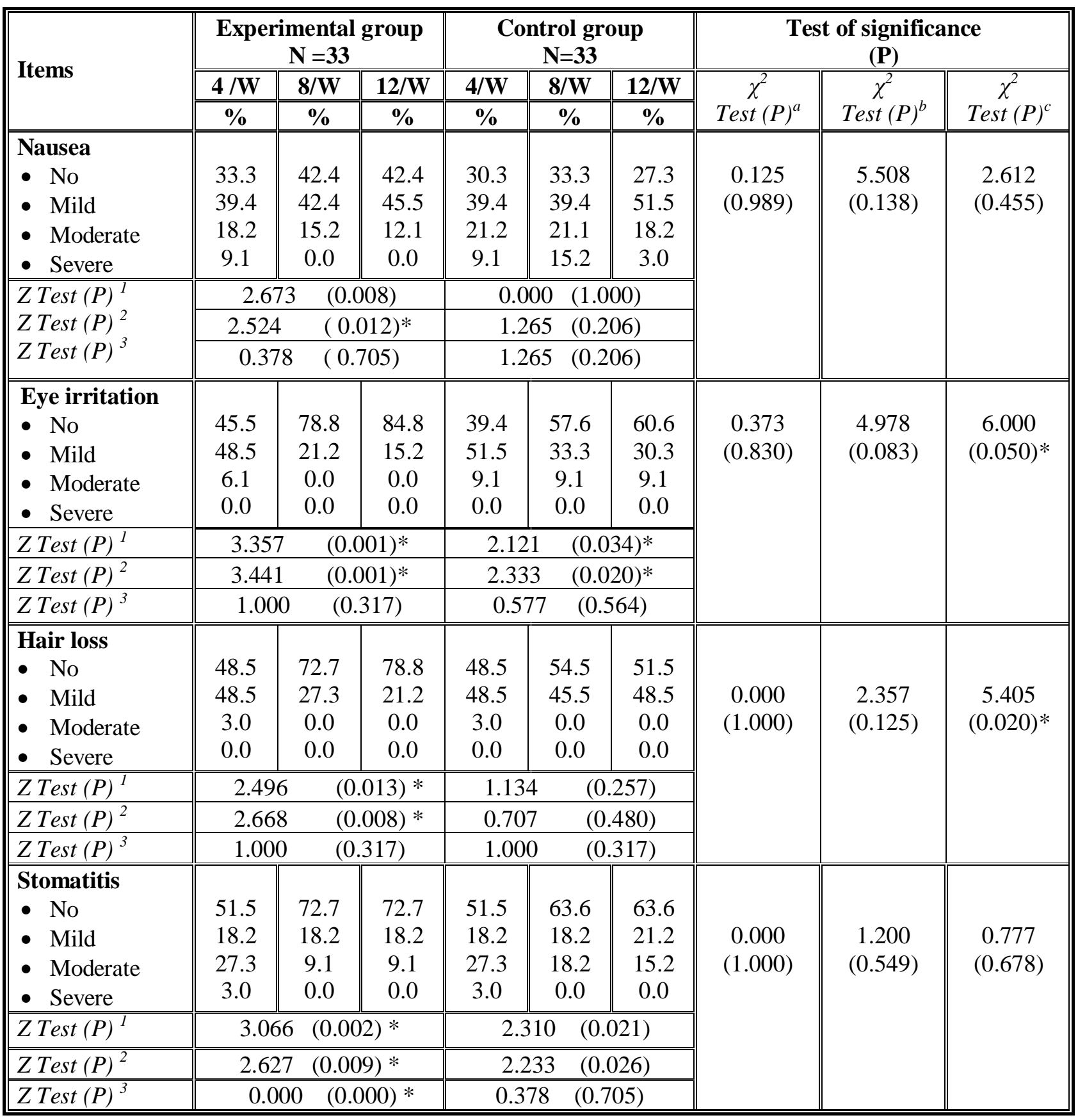

*Significant at $\mathrm{P} \leq 0.05$.

W: week. 
Table (4) (Continued): Effect of Nursing Intervention on Minor Side Effects of Interferon and Ribavirin among the Experimental and Control groups.

\begin{tabular}{|c|c|c|c|c|c|c|c|c|c|}
\hline \multirow{3}{*}{ Items } & \multicolumn{3}{|c|}{$\begin{array}{c}\text { Experimental group } \\
\mathbf{N}=\mathbf{3 3} \\
\end{array}$} & \multicolumn{3}{|c|}{$\begin{array}{c}\text { Control group } \\
\mathbf{N}=\mathbf{3 3} \\
\end{array}$} & \multicolumn{3}{|c|}{$\begin{array}{l}\text { Test of significance } \\
\text { (P) }\end{array}$} \\
\hline & $4 / W$ & $8 / \mathrm{W}$ & $12 / \mathrm{W}$ & 4/W & $8 / W$ & $12 / \mathrm{W}$ & \multirow{2}{*}{$\begin{array}{c}\chi^{2} \\
\text { Test }(P)^{a} \\
\end{array}$} & \multirow{2}{*}{$\begin{array}{c}\chi^{2} \\
\text { Test }(P)^{b}\end{array}$} & \multirow{2}{*}{$\begin{array}{c}\chi^{2} \\
\text { Test }(P)^{c}\end{array}$} \\
\hline & $\%$ & $\%$ & $\%$ & $\%$ & $\%$ & $\%$ & & & \\
\hline \multirow{4}{*}{\begin{tabular}{|ll} 
Anxiety \\
- No \\
- Mild \\
- Moderate \\
- Severe
\end{tabular}} & 545 & 667 & 727 & 545 & 576 & 576 & \multirow{7}{*}{$\begin{array}{c}0.000 \\
(1.000)\end{array}$} & \multirow{7}{*}{$\begin{array}{l}2.020 \\
(0.364)\end{array}$} & \multirow{7}{*}{$\begin{array}{c}2.055 \\
(0.358)\end{array}$} \\
\hline & 24.2 & 30.3 & 24.2 & 24.2 & 30.3 & 33.3 & & & \\
\hline & 21.1 & 3.0 & 3.0 & 21.2 & 12.1 & 9.1 & & & \\
\hline & 0.0 & 0.0 & 0.0 & 0.0 & 0.0 & 0.0 & & & \\
\hline \multirow{3}{*}{$\begin{array}{l}Z \text { Test }(P)^{1} \\
Z \text { Test }(P)^{2} \\
Z \text { Test }(P)^{3}\end{array}$} & \multicolumn{3}{|c|}{$2.887 \quad(0.004)^{*}$} & \multicolumn{3}{|c|}{$\begin{array}{ll}1.633 & (0.102) \\
\end{array}$} & & & \\
\hline & \multirow{2}{*}{\multicolumn{3}{|c|}{$\begin{array}{cc}2.556 & (0.011)^{*} \\
0.816 & (0.414)\end{array}$}} & \multicolumn{3}{|c|}{$1.667 \quad(0.096)$} & & & \\
\hline & & & & & $7 \quad(0$. & & & & \\
\hline \multirow{4}{*}{\begin{tabular}{ll}
\multicolumn{2}{l}{ Sexual problem } \\
- & No \\
- & Mild \\
- & Moderate \\
- & Severe
\end{tabular}} & 63.6 & 87.9 & 87.9 & 63.6 & 78.8 & 78.8 & \multirow{7}{*}{$\begin{array}{c}0.000 \\
(1.000)\end{array}$} & \multirow{7}{*}{$\begin{array}{l}1.564 \\
(0.458)\end{array}$} & \multirow{7}{*}{$\begin{array}{c}0.982 \\
(0.322)\end{array}$} \\
\hline & 33.3 & 12.1 & 12.1 & 33.3 & 18.2 & 21.2 & & & \\
\hline & 3.0 & 0.0 & 0.0 & 3.0 & 3.0 & 0.0 & & & \\
\hline & 0.0 & 0.0 & 0.0 & 0.0 & 0.0 & 0.0 & & & \\
\hline$Z$ Test $(P)^{l}$ & \multicolumn{3}{|c|}{$3.000 \quad(0.003)^{*}$} & \multicolumn{3}{|c|}{$1.000 \quad(0.317)$} & & & \\
\hline$Z$ Test $(P)^{2}$ & \multicolumn{3}{|c|}{$3.144 \quad(0.002)^{*}$} & \multicolumn{3}{|c|}{$1.811(0.070)$} & & & \\
\hline$Z \operatorname{Test}(P)^{3}$ & \multicolumn{3}{|c|}{1.604} & \multicolumn{3}{|c|}{$1.508 \quad(0.132)$} & & & \\
\hline
\end{tabular}

Pearson Chi-Square $\chi^{2}(P)^{a}$ : comparing experimental and control groups 4 week post intervention.

Pearson Chi-Square $\chi^{2}(P) b$ : comparing experimental and control groups 8 week post intervention.

Pearson Chi-Square $\chi^{2}(P)$ c: comparing experimental and control groups 12 week post intervention.

Wilcoxon Signed Ranks Z Test $(P)$ 1: comparing 4 and 8 week in each group.

Wilcoxon signed ranks $z$ test $(p)^{2}$ : comparing 4 and 12 week in each group.

Wilcoxon signed ranks $z$ test $(p)^{3}$ : comparing 8 and 12 week in each group.

*Significant at $\mathrm{P} \leq 0.05$. W: week. 
Table (5): Laboratory Investigation among the Experimental and Control Groups Pre Treatment and after 8 and 12 Weeks.

\begin{tabular}{|c|c|c|c|c|c|c|c|c|c|}
\hline \multirow[t]{3}{*}{$\overline{\text { Items }}$} & \multicolumn{3}{|c|}{$\begin{array}{c}\text { Experimental group } \\
\qquad \mathbf{N}=\mathbf{3 3} \\
\end{array}$} & \multicolumn{3}{|c|}{$\begin{array}{c}\text { Control group } \\
\mathbf{N}=\mathbf{3 3} \\
\end{array}$} & \multicolumn{3}{|c|}{$\begin{array}{l}\text { Test of significance } \\
(\mathrm{P})\end{array}$} \\
\hline & $\begin{array}{c}\text { Pre/tt } \\
\text { tt }\end{array}$ & $8 / W$ & $12 / \mathrm{W}$ & $\underset{t}{\operatorname{Pre} / \mathrm{tt}}$ & $8 / W$ & $12 / \mathrm{W}$ & $\begin{array}{l}\chi^{2} \\
\text { Test } \\
(P)^{a}\end{array}$ & $\underset{\text { Test }(P)^{b}}{\chi^{2}}$ & $\begin{array}{c}\chi^{2} \\
\text { Test } \\
(P)^{c}\end{array}$ \\
\hline & $\%$ & $\%$ & $\%$ & $\%$ & $\%$ & $\%$ & & & \\
\hline $\begin{array}{l}\text { Hemoglobin } \\
\text { - Normal } \\
\text { - Abnormal }\end{array}$ & $\begin{array}{c}97.0 \\
3.0\end{array}$ & $\begin{array}{l}57.6 \\
42.4\end{array}$ & $\begin{array}{c}90.9 \\
9.1\end{array}$ & $\begin{array}{c}97.0 \\
3.0\end{array}$ & $\begin{array}{l}30.3 \\
69.7\end{array}$ & $\begin{array}{l}54.5 \\
45.5\end{array}$ & $\begin{array}{c}0.000 \\
(1.000)\end{array}$ & $\begin{array}{c}4.982 \\
(0.026)^{*}\end{array}$ & $\begin{array}{c}11.000 \\
(0.001)^{*}\end{array}$ \\
\hline$Z$ Test $(P)^{I}$ & \multicolumn{3}{|c|}{$\mathrm{Z}=3.357 \quad(0.001)^{*}$} & \multicolumn{3}{|c|}{$\mathrm{Z}=4.690 \quad(0.000)^{*}$} & & & \\
\hline$Z$ Test $(P)^{2}$ & \multicolumn{3}{|c|}{$\mathrm{Z}=3.317 \quad(0.001)^{*}$} & \multicolumn{3}{|c|}{$\mathrm{Z}=2.309 \quad(0.021)^{*}$} & & & \\
\hline $\begin{array}{l}\text { White blood } \\
\text { cells (WBCs) } \\
\text { - Normal } \\
\text { - Abnormal }\end{array}$ & $\begin{array}{l}97.0 \\
3.0\end{array}$ & $\begin{array}{l}75.8 \\
24.2\end{array}$ & $\begin{array}{l}87.9 \\
12.1\end{array}$ & $\begin{array}{c}100.0 \\
0.0\end{array}$ & $\begin{array}{l}57.6 \\
42.4\end{array}$ & $\begin{array}{l}66.7 \\
33.3\end{array}$ & $\begin{array}{c}1.015 \\
(0.314)\end{array}$ & $\begin{array}{c}2.455 \\
(0.117)\end{array}$ & $\begin{array}{c}4.227 \\
(0.040)^{*}\end{array}$ \\
\hline $\begin{array}{l}Z \text { Test }(P)^{1} \\
Z \text { Test }(P)^{2} \\
\end{array}$ & \multicolumn{3}{|c|}{$\mathrm{Z}=2.333(0.020)^{*}$} & \multicolumn{3}{|c|}{$\mathrm{Z}=3.742 \quad(0.000)^{*}$} & & & \\
\hline $\begin{array}{l}\text { Red blood } \\
\text { cells(RBCs) } \\
\text { - Normal } \\
\text { - Abnormal }\end{array}$ & $\begin{array}{l}81.8 \\
18.2\end{array}$ & $\begin{array}{l}66.7 \\
33.3\end{array}$ & $\begin{array}{l}78.8 \\
21.2\end{array}$ & $\begin{array}{l}81.8 \\
18.2\end{array}$ & $\begin{array}{l}60.6 \\
39.4\end{array}$ & $\begin{array}{l}54.5 \\
45.5\end{array}$ & $\begin{array}{c}0.000 \\
(1.000)\end{array}$ & $\begin{array}{c}0.262 \\
(0.609)\end{array}$ & $\begin{array}{c}4.364 \\
(0.037)^{*}\end{array}$ \\
\hline $\begin{array}{l}Z \text { Test }(P)^{1} \\
Z \text { Test }(P)^{2} \\
\end{array}$ & \multicolumn{3}{|c|}{$\mathrm{Z}=1.291(0.019)^{*}$} & \multicolumn{3}{|c|}{$\mathrm{Z}=1.807 \quad(0.071)$} & & & \\
\hline $\begin{array}{l}\text { Platelets } \\
\text { - Normal } \\
\text { - Abnormal }\end{array}$ & $\begin{array}{c}100.0 \\
0.0\end{array}$ & $\begin{array}{l}66.7 \\
33.3\end{array}$ & $\begin{array}{l}81.8 \\
18.2\end{array}$ & $\begin{array}{c}100.0 \\
0.0\end{array}$ & $\begin{array}{l}57.6 \\
42.4\end{array}$ & $\begin{array}{l}57.5 \\
42.4\end{array}$ & $\begin{array}{c}0.000 \\
(1.000)\end{array}$ & $\begin{array}{c}0.580 \\
(0.447)\end{array}$ & $\begin{array}{c}4.591 \\
(0.032)^{*}\end{array}$ \\
\hline$\overline{Z \text { Test }(P)^{I}}$ & \multicolumn{3}{|c|}{$\mathrm{Z}=3.317 \quad(0.001)^{*}$} & \multicolumn{3}{|c|}{$\mathrm{Z}=3.317 \quad(0.001)^{*}$} & & & \\
\hline$Z$ Test $(P)^{2}$ & \multicolumn{3}{|c|}{$\bar{Z} \mathrm{Z}=1.890 \quad(0.059)$} & \multicolumn{3}{|c|}{$\mathrm{Z}=0.000 \quad(1.000)$} & & & \\
\hline
\end{tabular}

*Significant at $\mathrm{P} \leq 0.05$.

$\mathrm{ttt}$ : treatment 
Table (5) (Continued): Laboratory Investigation among the Experimental and Control Groups Pre Treatment and after 8 and 12 Weeks.

\begin{tabular}{|c|c|c|c|c|c|c|c|c|c|}
\hline \multirow[t]{3}{*}{$\overline{\text { Items }}$} & \multicolumn{3}{|c|}{$\begin{array}{c}\text { Experimental group } \\
\qquad \mathbf{N}=\mathbf{3 3} \\
\end{array}$} & \multicolumn{3}{|c|}{$\begin{array}{c}\text { Control group } \\
\mathbf{N}=\mathbf{3 3} \\
\end{array}$} & \multicolumn{3}{|c|}{$\begin{array}{l}\text { Test of significance } \\
(\mathbf{P})\end{array}$} \\
\hline & $\underset{t}{\operatorname{Pre} / \mathrm{tt}}$ & $8 / W$ & $12 / \mathrm{W}$ & $\begin{array}{c}\text { Pre/tt } \\
t\end{array}$ & $8 / W$ & $12 / \mathrm{W}$ & $\begin{array}{l}\chi^{2} \\
\text { Test } \\
(P)^{a}\end{array}$ & $\begin{array}{c}\chi^{2} \\
\text { Test }(P)^{b}\end{array}$ & $\begin{array}{c}\chi^{2} \\
\text { Test } \\
(P)^{c}\end{array}$ \\
\hline & $\%$ & $\%$ & $\%$ & $\%$ & $\%$ & $\%$ & & & \\
\hline $\begin{array}{l}\text { SGOT } \\
\text { - Normal } \\
\text { - Decreased } \\
\text { - Increased }\end{array}$ & $\begin{array}{c}100.0 \\
0.0 \\
0.0\end{array}$ & $\begin{array}{c}69.7 \\
30.3 \\
0.0\end{array}$ & $\begin{array}{c}84.8 \\
15.2 \\
0.0\end{array}$ & $\begin{array}{c}100.0 \\
0.0 \\
0.0\end{array}$ & $\begin{array}{c}66.7 \\
33.3 \\
0.0\end{array}$ & $\begin{array}{c}72.7 \\
27.3 \\
0.0\end{array}$ & $\begin{array}{c}0.000 \\
(1.000)\end{array}$ & $\begin{array}{c}0.070 \\
(0.792)\end{array}$ & $\begin{array}{c}1.451 \\
(0.228)\end{array}$ \\
\hline $\begin{array}{l}Z \text { Test }(P)^{I} \\
Z \text { Test }(P)^{2} \\
\end{array}$ & \multicolumn{3}{|c|}{$\mathrm{Z}=3.162 \quad(0.002)^{*}$} & \multicolumn{3}{|c|}{$\mathrm{Z}=3.317 \quad(0.001)^{*}$} & & & \\
\hline $\begin{array}{l}\text { SGPT } \\
\text { - Normal } \\
\text { - Decreased } \\
\text { - Increased }\end{array}$ & $\begin{array}{c}100.0 \\
0.0 \\
0.0\end{array}$ & $\begin{array}{c}72.7 \\
27.3 \\
0.0\end{array}$ & $\begin{array}{c}84.8 \\
12.1 \\
3.0\end{array}$ & $\begin{array}{c}100.0 \\
0.0 \\
0.0\end{array}$ & $\begin{array}{l}66.7 \\
21.2 \\
12.2\end{array}$ & $\begin{array}{l}69.7 \\
12.1 \\
18.2\end{array}$ & $\begin{array}{c}0.000 \\
(1.000)\end{array}$ & $\begin{array}{c}4.337 \\
(0.114)\end{array}$ & $\begin{array}{c}4.062 \\
(0.131)\end{array}$ \\
\hline $\begin{array}{l}Z \text { Test }(P)^{I} \\
Z \text { Test }(P)^{2} \\
\end{array}$ & \multicolumn{3}{|c|}{$\mathrm{Z}=3.000 \quad(0.000)^{*}$} & \multicolumn{3}{|c|}{$Z=3.035$} & & & \\
\hline $\begin{array}{l}\text { PCR } \\
\text { - Positive } \\
\text { - Negative }\end{array}$ & $\begin{array}{c}100.0 \\
0.0\end{array}$ & $\begin{array}{l}39.4 \\
60.6\end{array}$ & $\begin{array}{l}30.3 \\
69.7\end{array}$ & $\begin{array}{c}100.0 \\
0.0\end{array}$ & $\begin{array}{l}66.7 \\
33.3\end{array}$ & $\begin{array}{l}63.6 \\
36.4\end{array}$ & $\begin{array}{c}0.000 \\
(1.000)\end{array}$ & $\begin{array}{c}4.927 \\
(0.026)^{*}\end{array}$ & $\begin{array}{c}7.360 \\
(0.007)^{*}\end{array}$ \\
\hline$Z$ Test $(P)^{I}$ & \multicolumn{3}{|c|}{$\mathrm{Z}=4.472 \quad(0.000)^{*}$} & \multicolumn{3}{|c|}{$\mathrm{Z}=3.317 \quad(0.001)^{*}$} & & & \\
\hline$\overline{Z Z \text { Test }(P)^{2}}$ & \multicolumn{3}{|c|}{ 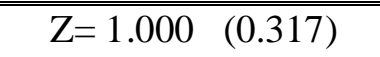 } & \multicolumn{3}{|c|}{ 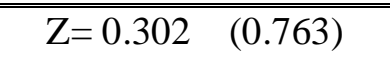 } & & & \\
\hline
\end{tabular}

Pearson Chi-Square $\chi^{2}(P)$ a: comparing experimental and control groups pre intervention.

Pearson Chi-Square $\chi 2(P) b$ : comparing experimental and control groups 8 week post intervention.

Pearson Chi-Square $\chi^{2}(P)$ c: comparing experimental and control groups 12 week post intervention.

Wilcoxon Signed Ranks $Z$ Test $(P)$ 1: comparing pre and 8 week post intervention in each group.

Wilcoxon signed ranks z test (p) 2: comparing 8 and 12 week post intervention in each group.

*Significant at $\mathrm{P} \leq 0.05$. $\mathrm{ttt}$ : treatment 
Nursing Interventions to Reduce Side Effects of Pegylated Interferon and Ribavirin

Table (6): Quality of Life of the Experimental and Control Groups Pre Treatment and Post 8 and 12 Weeks.

\begin{tabular}{|c|c|c|c|c|c|c|c|c|c|}
\hline \multirow{3}{*}{$\begin{array}{c}\text { Quality } \\
\text { of } \\
\text { life } \\
\text { (SF-36) }\end{array}$} & \multicolumn{3}{|c|}{ Experimental group ( 33 of elders) } & \multicolumn{3}{|c|}{ Control group ( $\mathbf{3 3}$ of elders) } & \multicolumn{3}{|c|}{$\begin{array}{l}\text { t- test } \\
(\mathrm{P})\end{array}$} \\
\hline & $\begin{array}{c}\text { Pre } \\
\text { treatment }\end{array}$ & $\begin{array}{c}8 \text { week } \\
\text { post } \\
\text { intervention }\end{array}$ & $\begin{array}{c}12 \text { week } \\
\text { Post } \\
\text { intervention }\end{array}$ & $\begin{array}{c}\text { Pre } \\
\text { treatment }\end{array}$ & $\begin{array}{c}8 \text { week } \\
\text { post } \\
\text { intervention }\end{array}$ & $\begin{array}{l}12 \text { week post } \\
\text { intervention }\end{array}$ & \multirow[t]{2}{*}{$\begin{array}{l}t \text {-test } \\
(P)^{a}\end{array}$} & \multirow[t]{2}{*}{$\begin{array}{l}t \text {-test } \\
(P)^{b}\end{array}$} & \multirow[t]{2}{*}{$\begin{array}{l}t \text {-test } \\
(P)^{c}\end{array}$} \\
\hline & MeantSD & MeantSD & MeantSD & MeantSD & MeantSD & Mean \pm SD & & & \\
\hline Physical functioning & $10.30 \pm 8.38$ & $21.97 \pm 12.68$ & $28.18 \pm 13.04$ & $11.06 \pm 10.51$ & $12.42 \pm 9.61$ & $5.00 \pm 9.01$ & $\begin{array}{c}0.317 \\
(0.752)\end{array}$ & $\begin{array}{c}3.466 \\
(0.001)^{*}\end{array}$ & $\begin{array}{c}8.401 \\
(0.000)^{*}\end{array}$ \\
\hline t-test (p) & \multicolumn{3}{|c|}{$10.193(0.000)^{*}$} & \multicolumn{3}{|c|}{$0.649 \quad(0.521)$} & & & \\
\hline t-test $(p)^{2}$ & \multicolumn{3}{|c|}{$13.502(0.000)^{*}$} & \multicolumn{3}{|c|}{$3.179(0.003)^{*}$} & & & \\
\hline t-test $(p)^{3}$ & \multicolumn{3}{|c|}{$6.723(0.000)^{*}$} & \multicolumn{3}{|c|}{$3.179 \quad(0.000)^{*}$} & & & \\
\hline $\begin{array}{l}\text { Role limitations due } \\
\text { to physical health }\end{array}$ & $1.52 \pm 6.06$ & $34.09 \pm 34.13$ & $57.58 \pm 30.29$ & $0.00 \pm 0.00$ & $9.09 \pm 23.23$ & $9.099 \pm 23.23$ & $\begin{array}{c}1.437 \\
(0.160)\end{array}$ & $\begin{array}{c}3.479 \\
(0.001)^{*}\end{array}$ & $\begin{array}{c}.296 \\
(0.000)^{*}\end{array}$ \\
\hline t-test $(p)^{I}$ & \multicolumn{3}{|c|}{$5.514(0.000)^{*}$} & \multicolumn{3}{|c|}{$2.248(0.032)^{*}$} & & & \\
\hline t-test $(p)^{2}$ & \multicolumn{3}{|c|}{$11.236(0.000)^{*}$} & \multicolumn{3}{|c|}{$2.248 \quad(0.032)^{*}$} & & & \\
\hline t-test $(p)^{3}$ & \multicolumn{3}{|c|}{$4.834 \quad(0.000)^{*}$} & \multicolumn{3}{|c|}{$0.000(1.000)$} & & & \\
\hline $\begin{array}{l}\text { Role limitations due } \\
\text { to } \quad \text { emotional } \\
\text { problem } \\
\end{array}$ & $5.05 \pm 12.14$ & $30.30 \pm 34.72$ & $40.40 \pm 36.09$ & $5.05 \pm 12.14$ & $13.54 \pm 22.17$ & $3.03 \pm 17.41$ & $\begin{array}{c}0.000 \\
(1.000)\end{array}$ & $\begin{array}{c}2.326 \\
(0.024)^{*}\end{array}$ & $\begin{array}{c}.358 \\
(0.000)^{*}\end{array}$ \\
\hline t-test $(p)^{I}$ & \multicolumn{3}{|c|}{$3.990 \quad(0.000)^{*}$} & \multicolumn{3}{|c|}{$2.104 \quad(0.044)^{*}$} & & & \\
\hline t-test $(p)^{2}$ & \multicolumn{3}{|c|}{$\begin{array}{ll}5.326 & (0.000)^{*}\end{array}$} & \multicolumn{3}{|c|}{$\begin{array}{ll}0.702 & (0.488)\end{array}$} & & & \\
\hline t-test $(p)^{3}$ & \multicolumn{3}{|c|}{$\begin{array}{ll}1.830 & (0.077)\end{array}$} & \multicolumn{3}{|c|}{$3.754 \quad(0.001)^{*}$} & & & \\
\hline Energy & $26.82 \pm 4.48$ & $35.76 \pm 5.61$ & $18.94 \pm 6.34$ & $25.76 \pm 3.98$ & $20.61 \pm 6.59$ & $18.94 \pm 6.34$ & 1.018 & 10.063 & 12.824 \\
\hline t-test $(p)^{I}$ & \multicolumn{3}{|c|}{$9.747 \quad(0.000)^{*}$} & \multicolumn{3}{|c|}{$4.360 \quad(0.000)^{*}$} & $(0.313)$ & $(0.000)^{*}$ & $(0.000)^{*}$ \\
\hline t-test $(p)^{2}$ & \multicolumn{3}{|c|}{$11.254 \quad(0.000)^{*}$} & \multicolumn{3}{|c|}{$5.555 \quad(0.000)^{*}$} & & & \\
\hline t-test $(p)^{3}$ & \multicolumn{3}{|c|}{$3.546 \quad(0.001)^{*}$} & \multicolumn{3}{|c|}{$\begin{array}{ll}2.766 \quad(0.000)^{*} \\
\end{array}$} & & & \\
\hline
\end{tabular}


Nursing Interventions to Reduce Side Effects of Pegylated Interferon and Ribavirin

Table (6) (Continued): Quality of Life of the Experimental and Control Groups Pre Treatment and Post 8 and 12 Weeks.

\begin{tabular}{|c|c|c|c|c|c|c|c|c|c|}
\hline \multirow{3}{*}{$\begin{array}{c}\text { Quality of } \\
\text { life } \\
(\mathrm{SF}-36)^{\#}\end{array}$} & \multicolumn{3}{|c|}{ Experimental group } & \multicolumn{3}{|c|}{ Control group } & \multicolumn{3}{|c|}{$\mathrm{t}$ - test $(\mathrm{P})$} \\
\hline & Pre treatment & $\begin{array}{c}8 \text { week } \\
\text { post } \\
\text { intervention }\end{array}$ & $\begin{array}{c}12 \text { week } \\
\text { Post } \\
\text { intervention }\end{array}$ & Pre treatment & $\begin{array}{c}8 \text { week } \\
\text { post } \\
\text { intervention } \\
\end{array}$ & $\begin{array}{l}12 \text { week post } \\
\text { intervention }\end{array}$ & \multirow[t]{2}{*}{$\begin{array}{l}\text { t-test } \\
(P)^{a}\end{array}$} & \multirow[t]{2}{*}{$\begin{array}{l}t \text {-test } \\
(P)^{b}\end{array}$} & \multirow[t]{2}{*}{$\begin{array}{l}t \text {-test } \\
(P)^{c}\end{array}$} \\
\hline & MeantSD & Mean \pm SD & MeantSD & Mean_SD & MeantSD & MeantSD & & & \\
\hline $\begin{array}{l}\text { Emotional well } \\
\text { being }\end{array}$ & $52.73 \pm 9.03$ & $59.88 \pm 8.21$ & $61.94 \pm 7.62$ & $52.36 \pm 7.90$ & $39.03 \pm 6.56$ & $36.61 \pm 6.17$ & $\begin{array}{c}0.174 \\
(0.862)\end{array}$ & $\begin{array}{l}11.393 \\
(0.000)^{*}\end{array}$ & $\begin{array}{l}14.834 \\
(0.000)\end{array}$ \\
\hline t-test $(p)^{I}$ & \multicolumn{3}{|c|}{$4.073 \quad(0.000)^{*}$} & \multicolumn{3}{|c|}{$\begin{array}{lll}7.281 & (0.000)^{*}\end{array}$} & & & \\
\hline$t$-test $(p)^{2}$ & \multicolumn{3}{|c|}{$\begin{array}{lll}5.724 & (0.000)^{*}\end{array}$} & \multicolumn{3}{|c|}{$\begin{array}{ll}8.265 & (0.000)^{*}\end{array}$} & & & \\
\hline t-test $(p)^{3}$ & \multicolumn{3}{|c|}{$\begin{array}{ll}3.400 \quad(0.002)^{*} \\
\end{array}$} & \multicolumn{3}{|c|}{$2.734 \quad(0.010)^{*}$} & & & \\
\hline Social functioning & $14.77 \pm 10.58$ & $29.55 \pm 17.06$ & $36.36 \pm 17.22$ & $15.53 \pm 11.28$ & $20.08 \pm 14.30$ & $11.36 \pm 10.53$ & 0.281 & 2.443 & 7.114 \\
\hline t-test $(p)^{I}$ & \multicolumn{3}{|c|}{$6.908 \quad(0.000)^{*}$} & \multicolumn{3}{|c|}{$1.359 \quad(0.184)$} & $(0.779)$ & $(0.017)^{*}$ & $(0.000)^{*}$ \\
\hline t-test $(p)^{2}$ & \multicolumn{3}{|c|}{$8.056 \quad(0.000)^{*}$} & \multicolumn{3}{|c|}{$\begin{array}{ll}1.609 & (0.117)\end{array}$} & & & \\
\hline $2 t$-test $(p)^{3}$ & \multicolumn{3}{|c|}{$\begin{array}{ll}4.157 \quad(0.000)^{*} \\
\end{array}$} & \multicolumn{3}{|c|}{$\begin{array}{ll}5.854 & (0.000)^{*} \\
\end{array}$} & & & \\
\hline Pain & $26.36 \pm 14.46$ & $37.58 \pm 13.68$ & $43.11 \pm 11.69$ & $31.36 \pm 12.56$ & $31.36 \pm 9.68$ & $22.27 \pm 11.65$ & 1.500 & 2.098 & 7.251 \\
\hline t-test $(p)^{I}$ & \multicolumn{3}{|c|}{$6.224 \quad(0.000)^{*}$} & \multicolumn{3}{|c|}{$0.000 \quad(1.000)$} & $(0.139)$ & $0.040)^{*}$ & $(0.000)^{*}$ \\
\hline t-test $(p)^{2}$ & \multicolumn{3}{|c|}{$7.889 \quad(0.000)^{*}$} & \multicolumn{3}{|c|}{$\begin{array}{ll}.891 \quad(0.000)^{*} \\
\end{array}$} & & & \\
\hline t-test $(p)^{3}$ & \multicolumn{3}{|c|}{$\begin{array}{ll}3.972 & (0.000)^{*}\end{array}$} & \multicolumn{3}{|c|}{$\begin{array}{ll}7.391 \quad(0.000)^{*} \\
\end{array}$} & & & \\
\hline General health & $13.94 \pm 9.90$ & $25.91 \pm 11.95$ & $33.03 \pm 12.50$ & $14.09 \pm 11.95$ & $13.03 \pm 11.18$ & $7.27 \pm 9.85$ & 0.056 & 4.521 & 9.299 \\
\hline t-test $(p)^{I}$ & \multicolumn{3}{|c|}{$8.206 \quad(0.000)^{*}$} & \multicolumn{3}{|c|}{$0.960 \quad(0.344)$} & $(0.955)$ & $(0.000)^{*}$ & $(0.000)^{*}$ \\
\hline t-test $(p)^{2}$ & \multicolumn{3}{|c|}{$\begin{array}{ll}11.677 \quad(0.000)^{*} \\
\end{array}$} & \multicolumn{3}{|c|}{$\begin{array}{ll}4.121 \quad(0.000)^{*} \\
\end{array}$} & & & \\
\hline t-test $(p)^{3}$ & \multicolumn{3}{|c|}{$\begin{array}{ll}9.066 & (0.000)^{*}\end{array}$} & \multicolumn{3}{|c|}{$\begin{array}{ll}4.90 & (0.000)^{*}\end{array}$} & & & \\
\hline
\end{tabular}

Student t-test $(P)^{1}$ : comparing pre treatment and 8 week in each group.

Student t-test $(P)^{2}$ : comparing pre treatment and 12 week in each group.

Student t-test $(P)^{3}$ : comparing 8 treatment and 12 week in each group.

Paired -sample t-test $(P)^{a}$ comparing experimental and control group pre intervention.

Paired-sample t-test $(P)^{b}$ : comparing experimental and control groups 8 weeks post intervention.

Paired -sample t-test $(P)^{c}$ : comparing experimental and control groups 12 weeks post intervention.

\#SF-36 Health Survey Questionnaire (increased scores denote improvement). * *Significant, at $P \leq 0.05$

p: p value for Chi-square test FEp: $p$ value for Fisher Exact test $\quad *$ : Statistically significant at $p \leq 0.05$ 


\section{References}

1. Fried M. Side Effects of Therapy for Chronic Hepatitis C and their Management. Hepatology 2002; 36:237-244.

2. Hauser P. Neuropsychiatric Side Effects of HCV Therapy and their Treatment: Focus on IFN alpha-induced Depression. Gastroenterol Clin North Am 2004; 33: 35-50.

3. Torriani FJ, Rodriguez-Torres M, Rockstroh JK, Lissen E, Gonzale García J, Lazzarin A, Carosi G, Sasadeusz J, Katlama C, Montaner J, Sette H Jr, Passe S,De Pamphilis J, Duff F, Schrenk UM, Dieterich DT . Peginterferon alfa-2a plus Ribavirin for Chronic Hepatitis C Virus Infection in HIVInfected Patients. N Engl J Med 2004; 351:438-450.

4. Zic, I. Peg Interferon alpha/Ribavirin Combination Therapy for the Treatment of Hepatitis C Infection. Gastroenterology Nursing 2005; 28(4):317-328.

5. Grogan A, Timmins F. Implications Side Effects of Treatment in Patients with Hepatitis C for Nurse Specialist Practice. Australian Journal of Advanced Nursing 2007; 27(2).

6. Ali A, Ahmed H, Idrees M. Molecular Epidemiology of Hepatitis C Virus Genotypes in Khyber Pakhtoonkhaw of Pakistan. Virology Journal 2010; 7:203. Available at: http://www.virologyj.com/content/7/1/203/ ins2

7. Mohamoud YA, Mumtaz GR, Riome S. The Epidemiology of Hepatitis C Virus in Egypt: A systematic Review and Data synthesis. BMC Infect Dis 2013; 24 (13): 288. Available at: http://www.ncbi.nlm.nih.gov/pubmed/23799 878. Retrieved on: 2/7/2012.

8. Lehman. E. Dynamics of Liver Disease in Egypt. Published doctorate, USA, Michigan University, 2008.

9. World Health Organization. Hepatitis C Fact Sheet. 2011. Available from: http://www.who.int/mediacentre/factsheets/f s164/en/. Accessed February 8,
2012.January 2008, 25(1): 9-18. Decade out. Cleve Clin J Med 2004, 71(Suppl 3):S3-7.

10. Landefeld S, Palmer R, Johnston B. Current Geriatric Diagnosis and Treatment. Singapore McGraw Hill Co. 2004; 234-38.

11. Francesca C. Hepatitis C Virus and Human Immunodeficiency Virus Transmission routes: Differences and similarities. World J Hepatol 2013; 5(5):234-6.

12. Rambaldi A, Jacobs B, Iaquinto G, Gluud C. Alcoholic and/or Hepatitis B or C Liver Diseases- A Systematic CochranehepatoBilary Group Review with Meta-Analysis of Randomized Clinical Trials. AM J Gasteroenterol 2005; 100: 2583-91.

13. Bonkovsky H, Snow KK, Mallet PF, BackMadruga C, Fontana RJ, Sterling RK, Kulig CC, Di Bisceglie AM, Morgan TR, Dienstag JL, Ghany MG, Gretch DR. Halt-C Trial Group. Health Related Quality of Life in Patient with Chronic Hepatitis $\mathrm{C}$ and Advanced Fibrosis. J Hepatol 2007; 46 (3):420-31.

14. Hassanein T. Treatment with 40KDA Peg Interferon alfa-2a (Pegasys) in Combination with Ribavirin Significantly Enhances Quality of Life Compared with Interferon alfa-2b Plus Ribavirin. EASL 2002; Abstract 622.

15. Afdhal N, Dieterich D, and Pockros P. Treatment of Anemic Hepatitis C Infected Patients Allows for Maintenance of Ribavirin Dose, Increases Hemoglobin Levels and Improves Quality of Life versus Placebo: A Randomized, Double-Blind, Multicenter Trial. Hepatology 2003; 124: 714.

16. Karaivazoglou K, Iconomou G, Triantos C, Hyphantis T, Thomopoulos K, Lagadinou M, Gogos C, Labropoulou-Karatza C, Assimakopoulos K. Fatigue and Depressive Symptoms Associated with Chronic Viral Hepatitis Patients. Health Related Quality of Life (HRQOL). Ann Hepatol 2010; 9:419-427.

17. Zucker, DM, Miller BW. Assessment of Side Effects in21-Patients with Chronic Hepatitis C Receiving Combination 
Therapy. Gastroenterology Nursing 2001; 24(4):192-196.

18. Strauss E, Dias Teixeira MC. Liver Int. Quality of Life in Hepatitis C. Gastroenterology \& Hepatology 2006; 26(7):755-. Available at: http://www.liver.eg.org/postgraduate, links.htm.

19. Svirtlih N, Pavic S, Terzic D, Delic D, Simonovic J, Gvozdenovic E, Boricic I. Reduced Quality of Life 12 Questioners. Gastrointestinal Liver Dis 2008; 17 (4):40509.

20. Wilhelmson K, Anderson CH. Aging and Society. Cambridge University; Press; 2005:5.- 16.

21. Peck-radosavljevic M, Wichlas M, Homoncik-kraml M, Kreil A, Hofer H, Jessner W, Gangl A, Ferenci P. Rapid Depression of Hemtopoiesis by standard or peglated interferon-alpha. Gastroenterology 2002; 123:141-151.

22. Luc M, Porte I. Aging and Hepatitis.3rd.USA, San Francisco. Hepatitis Advocate Center; 1-15.

23. Floreani A. Should Antiviral Therapy to be offered to Elderly Patients. Gasteroenterology and Hepatology 2009; 6.

24. Lankarani B. How to Manage Side Effects of Interferon Alpha Therapy in Chronic Hepatitis C. J Hepat 2004; 4(6):5-8.

25. Black J, Hawks J. Medical Surgical Nursing Clinical Management for Positive outcomes. 7th.ed.London, W.B. Saunders Company 2005; 1103-18.

26. Morisco F, Vitaglione P, Amorous D, Russo B, and Fogliano V. Foods and Liver Health. MOL Aspects Med 2008; 29(1):144-50.

27. Sobhonslidsuk A, Silpakit C, Kongsakon R. Factors Influencing Health Related Quality of Life in Chronic Liver Disease. World J Gastroenterol 2006; 12(48): 7786-91.

28. Bernstein DE, Kleinman L, Barker CM Revicki DA, Green J. Relationship of Health Related Quality of Life to Treatment Adherence and Sustained Response in
Chronic Hepatitis C Patients. Hepatology 2002; 35: 704-708.

29. Ware JE Jr, Sherbourne CD. The MOS 36item Short-Form Health Survey (SF-36). I. Conceptual Framework and Item Selection. Med Care 1992; 30:473-83.

30. Amodio P, Salar Li, Montagne $\mathrm{S}$, et al. Hepatitis C Virus Infection and HealthRelated Quality of Life. World J Gastroenterol 2012; 18(19): 2295-2299.

31. Hassan E. Effect of Discharge Plan on the Quality of Life of Acute Myocardial Infarction among Elderly Patients. Published Doctoral Thesis, Faculty of Nursing; Mansoura University, 2014.

32. Krupp LB1, LaRocca NG, Muir-Nash J, Steinberg AD. The Fatigue Severity Scale. Application to Patients with Multiple Sclerosis and Systemic Lupus Erythematosus. Arch Neurol 1989; 46(10):1121-3.

33. Mohsen M, Fareed M, Amal A, Abbas S et al. Effect of Nursing Management Protocol on Selected Side Effects of Interferon and Ribavirin among Hepatitis C Patients. Journal of American Science 2011; 7(6).

34. Fried MW, Shiffman ML, Reddy KR. Combination of Peginterferon alfa-2b Plus Ribavirin in Patients with Chronic Hepatitis $\mathrm{C}$ virus Infection. N Eng J Med 2002; 347: 975-982.

35. Bianchi C, Loguerciol C, Sgarbi D Abbiati R, Chen CH, Di Pierro M, Disalvo D, Natale S, Marchesini G. Reduced Quality of Life in Patients with Chronic Hepatitis C: Effects of Interferon Treatment. Digest liver IS. 2000; 32: 399-405.

36. Arase Y, Ikeda K, Suzuki F, Suzuki Y, Saitoh S, Kobayashi M, Akuta N, Someya T, Koyama R, Hosaka T, Sezaki H, Kobayashi M, Kumada H. Long-Term Outcome after Interferon Therapy in Elderly Patients with Chronic Hepatitis C. Intervirology 2007; 50(1): 16-23.

37. Koyama R, Arase Y, Ikeda K, Suzuki F, Suzuki Y, Saitoh S, Kobayashi M, Akuta N, Someya T, Hosaka T, Sezaki H, Kobayashi M, Kumada H. Efficacy of 
Interferon Therapy in ElderlyPatients with Chronic Hepatitis C. Intervirology 2006; 49: 121-126.

38. Terranova R, Luca S. Different Types of Interferon for the Therapy of HCV Chronic Active Hepatitis in the Elderly Patient. European Review for Medical and Pharmacological Sciences 1999; 3: 45-52.

39. Sobhonslidsuk A, Silpakit C, Kongsakon R Satitpornkul P, SripetchC, Khanthavit A. Factors Influencing Health-Related Quality of Life in Chronic Liver Disease World J Gastroenterol 2006; 12(48): 7786-7791.

40. Kallman J, O'Neil MM, Larive B, Boparai N, Calabrese L, Younossi ZM. Fatigue and Health Related Quality of Life in Chronic Hepatitis C Virus Infection. Dig Dis Sci 2007; 52: 2531-2539.

41. Heneedy W. Study of the Effect of Nursing Intervention on Physical Responses and Compliance among Patients with Liver Cirrhosis at National Liver Institute and Menoufyia University Hospital. Published Doctoral Thesis, Faculty of Nursing; Menoufyia University, 2009.

42. Sarker s, Jiang z, Evon D Wahed A, Hoofnagle J. Fatigue before, during, and after Antiviral Therapy of Chronic Hepatitis C Therapy: Results from the viral hep-Cstudy. J Hepatology 2012; 06-030.

43. Seyam, MS, Freshwater DA, O'Donnell. Weight Loss during Pegylated Interferon and Ribavirin Treatment of Chronic Hepatitis C. Journal of Viral Hepatitis 2005; 12(5):531-535.

44. Huang CF, Yang JF, and Dai CY, Hou NJ, Hsieh MY, Lin ZY, Chen SC, Hsieh MY, Wang LY, Chang WY, Chuang WL, Yu ML. Efficacy and Safety of Pegylated Interferon Combined with Ribavirin for the Treatment of Older Patients with Chronic Hepatitis C. Journal of Infectious Diseases 201(5): 751-759 (Abstract). March 1, 2010.

45. Mulhall, BP, Younossi Z. Impact of Adherence on the Outcome of Antiviral Therapy for Chronic Hepatitis C. Journal of Clinical Gastroenterology 2005, 39(1 Suppl.): S23-27.
46. Fareed M. Dietary Management in Chronic Renal Failure Patients and its Effects on Nutritional States, Renal Function Tests and Serum Electrolytes. Published Doctoral degree, Faculty of Nursing; Menoufyia University, 2004.

47. El-Shikh A. The Impact of a Protocol of Care on Physical Responses and Compliance among Patients with Congestive Heart Failure. Published Doctoral degree. Faculty of Nursing; Menoufyia University, 2003.

48. Alavian S, Kabir A, Hajarizadeh B, Pharm M, D, Beigi B, Doroudi T, Baralle F. Preliminary report of Interferon Alfa $2 b$ in Combination with Ribivirin for 48 weeks for Treatment of Iranian Patients with Chronic Hepatitis C: A quasi-experimental study. Shiraz E-Medical Journal 2006; 7(1): 1- 11.

49. Bonkovsky HL Woolley JM. The Consensus Interferon Study Group. Reduction of Health-Related Quality of Life in HCV and Improvement with Interferon Therapy. Hepatology 1999; 264-270.

50. Chao Kang S, Hwang S, Lee S, Chang F, Lee C. Health-Related Quality of Life and Impact of Antiviral Treatment in Chinese Patients with Chronic Hepatitis C in Taiwan. World J Gastroenterol 2005; 11(47): 74947498. 